\title{
U.S. AIRLINES AND ANTITRUST: THE STRUGGLE FOR DEFENSIBLE POLICY TOWARDS A UNIQUE INDUSTRY
}

\author{
DANIEL J. GIFFORD* \\ ROBERT T. KUDRLE*
}

The Justice Department has recently approved a series of mergers in the airline industry that look very questionable in light of its own merger guidelines. This Article attempts to explain the Justice Department's decisions.

\section{INTRODUCTION}

Delta Airlines and Northwest Airlines announced their agreement to merge in April 2008. ${ }^{1}$ The Justice Department approved the merger later that year. ${ }^{2}$ On May 3, 2010, barely two years after the Delta/Northwest announcement, United Airlines and Continental Airlines announced their intention to merge. ${ }^{3}$ The Justice Department approved the merger and it was consummated later that same year. ${ }^{4}$ Southwest Airlines and AirTran announced merger plans in 2011 and consummated that merger in 2015. In February 2013, American Airlines and US Air announced their intention to merge. ${ }^{6}$ The Justice Department initially brought suit to block the merger, ${ }^{7}$ but later (on November 12,2013) reached a settlement

* Robins Kaplan Emeritus Professor of Law, University of Minnesota Law School.

** Orville \& Jane Professor of International Trade \& Investment Policy, Humphrey School of Public Affairs and the Law School, University of Minnesota.

1. Lisa Stark et al., Delta and Northwest Announce Merger, ABC News (Nov. 8, 2016, 3:40 $\mathrm{PM}$ ), http://abcnews.go.com/WN/BusinessTravel/delta-northwest-announcemerger/story?id=4650633 [https://perma.cc/P7VU-SG8X].

2. Martin Moylan, Justice Department Approves Northwest-Delta Merger, MPR NEwS (Nov. 8, 2016, 3:45 PM), http://www.mprnews.org/story/2008/10/29/northwest_delta_merger_ approved [https://perma.cc/8YGR-R2JS].

3. United and Continental Announce Merger, N.Y. Times (Nov. 8, 2016, 3:53 PM), http://dealbook.nytimes.com/2010/05/03/united-and-continental-announce-merger/?_r=0 [https://perma.cc/FFA3-QSA2].

4. Gregory Karp, American, US Airways Complete Merger: United Airlines Loses Title as World's Largest Airline, CHI. TRIB. (Nov. 8, 2016, 4:20 PM), http://articles.chicagotribune. com/2013-12-09/business/chi-american-airlines-merger-20131209_1_us-airways-ceo-ceo-dougparker-united-airlines [https://perma.cc/5KMS-8Q3G].

5. Terry Maxon, Now Departing: AirTran Airways Flies Offinto the Sunset After Southwest Merger, DALl. News (Nov. 8, 2016, 5:00 PM), http://www.dallasnews.com/business/airlines/2014/ $12 / 27$ /now-departing-airtran-airways-flies-off-into-the-sunset-after-southwest-merger [https://perma.cc/XS8K-JG77].

6. Linda Wertheimer \& Wade Goodwyn, American, US Airways Announce Merger, NPR (Nov. 8, 2016, 5:11 PM), http://www.npr.org/2013/02/14/171975386/merger-deal-expected-foramerican-u-s-airways [https://perma.cc/86X4-6WET].

7. See Competitive Impact Statement at 8, United States v. US Airways Grp., Inc., 38 F. Supp. 3d 69 (D.D.C. 2014) (No. 1:13-cv-01236) [hereinafter CIS]. 
with the parties and approved the merger. ${ }^{8}$ Under the settlement, the airlines agreed to divert gates and slots (take-off and landing rights) at seven major airports. ${ }^{9}$ After these mergers, the United States domestic market contains four large airlines, each holding a share between fourteen and twenty percent of the domestic air travel market. ${ }^{10}$ (Because AirTran only held about a 3.5\% market share, the Southwest/AirTran merger does not raise market-concentration issues similar to those of the other three mergers).

The airline industry shows a four-firm national concentration level based on airline passenger miles of about seventy percent while four-firm concentration based on the shares of all domestic ticketed passengers is close to eighty percent. ${ }^{11}$ Although the Herfindahl-Hirschman Index (HHI) for airlines passenger miles of 1489.3 indicates an un-concentrated market, there is general agreement that national concentration levels, however calculated, are of secondary importance. ${ }^{12}$ City-pair market concentration far better reflects the market power of the carriers, and this is the focus of official attention. ${ }^{13}$ Mergers have eliminated competition between the merger participants, and many city-pair markets have much higher concentration ratios and HHI levels than the industry as a whole. ${ }^{14}$ The government's complaint in the American/US Air merger, for example, lists 460 city-pair markets that the guidelines would treat as presumptively unlawful as the result of that merger because their HHI would

8. Jad Mouawad \& Christopher Drew, Justice Dept. Clears Merger of 2 Airlines, N.Y. TiMES (Nov. 9, 2016, 1:04 PM), http://dealbook.nytimes.com/2013/11/12/u-s-said-to-be-nearsettling-american-us-airways-merger-lawsuit/?_r=0 [https://perma.cc/M82D-Z7D8].

9. See Complaint at Appendix A, US Airways Grp., Inc., 38 F. Supp. $3 d 69$ (No. 1:13-cv01236).

10. The most recent government data (November 2015 - October 2016) lists the market shares of these carriers as American 19.3\%, Southwest 18.3\%, Delta 16.9\%, United 14.5\%. Bureau of Transportation Statistics, U.S. DEP'T OF TRANSP., http://www.transtats.bts.gov/ [https://perma.cc/ WHR6-LNUK] (last visited Jan. 18, 2017). The market shares are based on passenger revenue miles. Id. Later references will be to BTS TranStats. The categories of unconcentrated, moderately concentrated, etc. are from the U.S. Department of Justice and FTC, Horizontal Merger Guidelines. See infra notes 226-29.

11. Fiona Scott Morton et al., Benefits of Preserving Consumers Ability to Compare Airline Fares, Travel TeCH. Ass'N 1, 35-37 (2015), http://www.traveltech.org/wp-content/uploads/ 2015/05/CRA.TravelTech.Study_.pdf [https://perma.cc/RB5K-MTUC].

12. See $i d$. The index is a measure of industry concentration used in the merger guidelines of the Department of Justice and the Federal Trade Commission. Id. at 35. The index is calculated by squaring the percentage market share of each firm in the industry and adding them. Id. Therefore, the maximum possible value of a monopoly is $10,000\left(100^{2}\right)$. Id. at 36 . Because the HHI is constructed from the squares of market shares, it yields a higher number as shares are larger on average and also as the shares are more unequal.

13. U.S. Gov't Accountability Off., GAO-14-515, Airline Competition: The Average Number of Competitors in Markets Serving the Majority of Passengers Has Changed Little in Recent Years, But Stakeholders Voice Concerns about Competition 9 (2015).

14. Morton et al., supra note 11, at 36. 
exceed 2500 and the merger would raise the index by over 200 points. $^{15}$ Discussing the overall situation in 2014 , one study concluded: "[N]early 90 percent of all passengers traveled on city-pairs with HHIs above 2,500, and about 40 percent of city pairs have HHIs in excess of 4,000." ${ }^{\prime 16}$ Why has the DOJ acquiesced to this increased concentration?

This Article examines the evolution of government policy that has culminated in the approval of the recent airline mergers and the apparent approach of the Justice Department in evaluating them. ${ }^{17}$ What rationales for the mergers did the DOJ accept and what do they tell us about merger evaluation in the Department? ${ }^{18}$ That discussion is preceded by a brief sketch of the industry, ${ }^{19}$ the relevant markets used for antitrust in the industry, ${ }^{20}$ the nature of industry cost ${ }^{21}$ determinants of consumer demand, ${ }^{22}$ competitive behavior in the industry, ${ }^{23}$ the importance of politically-controlled complementary inputs,${ }^{24}$ and general antitrust activity in the industry. ${ }^{25}$

\section{THE U.S. AIRLINE INDUSTRY: HISTORY AND CHARACTERISTICS}

\section{A. From Regulation to Deregulation}

After four decades of regulation during which airline fares and routes were subject to the control of the Civil Aeronautics Board (CAB), Congress opted to deregulate the airline industry in $1979 .{ }^{26}$ Prior to deregulation, the industry was composed of eleven trunk carriers and twelve local service carriers. ${ }^{27}$ Subsequent to deregulation many new carriers entered the market. ${ }^{28}$ As of the mid-1980s, the

15. See Complaint at Appendix A, United States v. US Airways Grp., Inc., 38 F. Supp. 3d 69 (D.D.C. 2014) (No. 1:13-cv-01236).

16. Morton et al. supra note 11, at 36. For example, an HHI of 2500 in a city-pair market could mean that it is being served by four equal-sized airlines, and a market with an HHI of above 4000 could mean that it is being served by three airlines of somewhat unequal size.

17. See infra Part I.

18. See infra Part II.C.

19. See infra Part I.A.

20. See infra Part I.B-C.

21. See infra Part I.D.

22. See infra Part I.E-F.

23. See infra Part I.G.

24. See infra Part I.H.

25. See infra Part I.I.

26. See William A. Jordan, Airline Entry Following U.S. Deregulation: The Definitive List of Startup Passenger Airlines, 1979-2003, at 1, TransP. ReS. F. (Mar. 6, 2005), http://www. trforum.org/forum/downloads/2005_Deregulation_paper.pdf[https://perma.cc/UVF5-9HGZ]; see also Airline Deregulation Act of 1978, Pub. L. No. 95-504, 92 Stat. 1705.

27. See Jordan, supra note 26, at 2-3.

28. John M. Kost, Effects of Airline Deregulation, MACKINAC CTR. (Nov. 9, 2016, 6:52 PM), https://www.mackinac.org/6358 [https://perma.cc/4EHR-76MV]. 
air carriers servicing the U.S. domestic market included Northwest, TWA, American, United, Continental, Braniff, Delta, US Air, Texas Air, People Express, Southwest, Piedmont, Ozark, and Republic. ${ }^{29}$ In 1986, Northwest merged with Republic and TWA acquired Ozark. ${ }^{30}$ In 1987, People Express was merged into Continental. ${ }^{31}$ Other mergers followed. ${ }^{32}$ Indeed, most of the entrants were gone by $1990 .^{33}$

Since deregulation, descriptions of the industry's structure have typically distinguished the so-called "legacy" carriers, those carriers that were operating before deregulation, from "low cost" carriers (LCCs) that began operating in the post-regulation period. ${ }^{34}$ Although the term LCC is very widely used, it carries two different connotations. One is that the latecomers have not been burdened with high labor costs generated or facilitated by regulation, which continued into the post-regulation period. ${ }^{35}$ The post-regulation entrants paid wages much closer to prevailing labor market conditions and made them low- (or lower-) cost operations compared with their older rivals. ${ }^{36}$ The other connotation is that the newcomers offer a rather Spartan product and can charge lower prices on that count alone. ${ }^{37}$ The two characteristics have typically gone together, but they should be distinguished.

A popular image long held the largest carriers were the legacies and that the low-cost carriers tended to be relatively small. ${ }^{38}$ This is no longer a true

29. See generally Jordan, supra note 26.

30. Carol Jouzaitis, Republic, Northwest to Merge, CHI. TRIB. (Nov. 9, 2016, 7:06 PM), $\mathrm{http} / / /$ articles.chicagotribune.com/1986-01-25/business/8601070312_1_republic-airlines-americanairlines-third-largest-airline [https://perma.cc/6Q9F-P3GW]; Reginald Stuart, T.W.A.-OzarkMerger Is Approved, N.Y. Times (Nov. 9, 2016, 7:15 PM), http://www.nytimes.com/1986/09/13/business/ company-news-twa-ozark-merger-is-approved.html [https://perma.cc/HJZ5-RNQH].

31. Robert E. Dallos, People Express Fades into History as Merger Is OKd, L.A. TIMES (Nov. 9, 2016, 7:18 PM), http://articles.latimes.com/1986-12-30/business/fi-1132_1_fares [https:// perma.cc/9ZG6-V4UQ].

32. See U.S. Airline Mergers and Acquisitions, AIRLINES FOR AM., http://airlines.org/data/u-sairline-mergers-and-acquisitions/ [https://perma.cc/7FL7-6BUT] (last visited Jan. 18, 2017).

33. Severin Borenstein \& Nancy L. Rose, How Airline Markets Work . . Or Do They?, in Economic Regulation and its Reform: What HaVe We Learned? 63, 87 (Nancy L. Rose ed., 2014) (noting forty-seven new airlines had entered the market by 1984 , but only seven still existed by 1990$)$.

34. Southwest is generally referred to as an LLC, although it began operating prior to deregulation as an intrastate carrier where it was exempt from CAB control. See id. at 80.

35. Paul Stephen Dempsey, Predation, Competition, and Antitrust Law: Turbulence in the Airline Industry, 67 AIR L. \& COM. 685, 703 (2002).

36. Id.

37. Id. (linking low fares to no-frills services).

38. See generally Tatiana Morales, Flying on Smaller and Low-Cost Airlines, CBS NEwS (July 23, 2002, 4:00 PM), http://www.cbsnews.com/news/flying-on-smaller-and-low-cost-airlines/ [https://perma.cc/TQ67-2TNF] (splitting airlines into major airlines versus small and low-cost airlines as categories for comparison). 
description of the industry. Prior to the merger of Delta and Northwest, Southwest, an LCC, was the largest airline in the U.S. market. ${ }^{39}$ Currently, the U.S. domestic airline industry is composed of the four large U.S. carriers all of which have recently merged and several LCCs, the largest of which is JetBlue with a market share of $5.5 \% .{ }^{40}$ The remaining carriers also include Alaska, Spirit, SkyWest, Frontier, Hawaiian, Virgin America and Allegiant Air. ${ }^{41}$ These carriers compete with Southwest and the three legacy carriers on many routes.

\section{B. Financial Performance and Bankruptcies}

Along with the prevalence of mergers, the industry has been distinguished by its dismal financial performance since the onset of deregulation. ${ }^{42}$ In 2011, Severin Borenstein, perhaps the closest student of the airline industry, wrote a widely cited article in the American Economic Review calling attention to the chronic losses incurred by the industry stating, "The industry lost $\$ 10$ billion from 1979 to 1989 , made $\$ 5$ billion in the 1990s and lost $\$ 54$ billion from 2000 to 2009 (all figures in 2009 dollars)." ${ }^{, 43}$ Borenstein titled his article "Why Can't US Airlines Make Money?" challenging scholars and others to explain these repeated losses. ${ }^{44}$ As he observed, "There is no conventional long-run equilibrium explanation for an industry that perpetually loses money." ${ }^{45}$ In a 2008 article, Paul Stephen Dempsey summarized the industry financial experience, stating that by the end of 1991, the industry had lost all the profit that it had previously earned plus another $\$ 2$ billion. ${ }^{46}$ It would recover in the late 1990s, and then lose it again in the early twenty-first century, suffering losses in every year but one from 2001 through 2009. ${ }^{47}$ But both Dempsey and Borenstein wrote before the recent resurgence of airline profitability following the Great Recession.

39. December 2010 Airline System Traffic Up 2.9 Percent from December 2009, U.S. DEP'T OFTRANSP.(Mar. 11, 2011),http://www.rita.dot.gov/bts/sites/default/files/rita_archives/bts_press_ releases/2011/bts014_11/pdf/bts014_11.pdf [https://perma.cc/CHH6-PLBT].

40. Bureau of Transportation Statistics, supra note 10.

41. U.S. Certificated Air Carriers, U.S. DeP'T of Transp. (May 29, 2015), https://www. transportation.gov/sites/dot.gov/files/docs/Certificated\%20Air\%20Carrier\%20List_1.pdf [https://perma.cc/B3X4-H5YC].

42. Severin Borenstein, Why Can't US Airlines Make Money? 101 Am. Econ. Rev. 233, 233

(2011) (describing the financial record of the airline industry post-regulation as dismal).

43. Id.

44. Id. at 236 (calling for more research by industrial organization economists).

45. Id. at 233.

46. Paul Stephen Dempsey, The Financial Performance of the Airline Industry PostDeregulation, 45 Hous. L. REV. 421, 427 (2008).

47. Id. at 424-25 (showing the airline industry lost money in 1981, 1982, 1983, 1986, 1990, 1991, 1992, 1993, 2001, 2002, 2003, 2004, 2005, and 2006); Borenstein, supra note 42, at 234 (indicating airline losses in 2008 and 2009). 


\section{Long-Term Price Decline; Long-Term Growth; Volatile Environment}

Average passenger fares have been falling over the past two decades. Measured in 2015 dollars, the average fare was $\$ 454$ in 1995; in 2015 it was $\$ 377$, or seventeen percent less. ${ }^{48}$ From 2002 to 2015 , output, as measured in available seat miles, has increased from $670,252,981$ to $742,617,500 .{ }^{49}$ In 2015 total enplanements (passengers carried) reached 696,016,894 (domestic) exceeding the industry's 2007 pre-recession high of $679,185,450 .{ }^{50}$

As shown by the large number of unprofitable years noted, the airline industry operates in a highly volatile environment. Borenstein and Rose have argued that uncertainty about the right business model has typically led each carrier to engage in considerable expansion in good times only to suffer subsequent losses in downturns. ${ }^{51}$ Demand is growing secularly, but it drops significantly during periods of recession or when a threat of terrorism arises, and unpredictable fuel cost changes and labor unrest add to uncertainly. ${ }^{52}$ Thus the periods in which the industry incurred losses include the recessionary periods at the beginning of the $1980 \mathrm{~s}$, the similar period at the beginning of the $1990 \mathrm{~s}$, the period after the dot-com bubble, the period following the 9-11 terrorist attacks and the period of the so-called 'Great Recession. ${ }^{53}$

\section{Industry Cost Structure}

1. Large Fixed Costs.-The airline industry's fixed costs are large in relation to its variable costs. ${ }^{54}$ Moreover, industry practice is to set the airline's schedule three months in advance; this makes all costs (including even labor and fuel) fixed for that three-month period..$^{55}$ According to a number of industry critics, the heavy fixed-cost component combined with competition pushes price towards marginal cost, and large fixed costs ensure that average cost exceeds marginal

48. Annual U.S. Domestic Average Itinerary Fare in Current and Constant Dollars, U.S. DEP'T OF TRANSP., http://www.rita.dot.gov/bts/airfares/programs/economics_and_finance/air_ travel_price_index/html/AnnualFares.html [https://perma.cc/A8ZU-5QDR] (last visited Jan. 18, 2017).

49. Available Seat-Miles (the Number of Seats and the Distance Flown in Thousands) All Carriers-All Airports, U.S. DEP'T OF TRANSP., http://www.transtats.bts.gov/Data_Elements. aspx?Data $=4$ [https://perma.cc/8TV2-S3RX] (last visited Jan. 19, 2017).

50. See Bureau of Transportation Statistics: Passengers: All Carriers-All Airports, DEP'T OF TRANSP., http://www.transtats.bts.gov/Data_Elements.aspx?Data=1 [https://perma.cc/HPT7H4TE] (last visited Jan. 19, 2017).

51. Borenstein \& Rose, supra note 33, at 49.

52. Dempsey, supra note 46, at 430-31 (noting the losses following the 9/11 terrorist attacks, the recession of 1990-1994, the recession and fuel spike of 1981-1983, and depressed demand after the terrorist attack on Pan Am 103).

53. Bijan Vasigh, Ken Fleming \& Thomas Tacker, Introduction to Air Transport ECONOMICS: From THEORY TO APPLICATIONS 7 (2d ed. 2013).

54. See, e.g., id.

55. Id. at 265 . 
cost. ${ }^{56}$

There are two major approaches linking large fixed costs to industry profitability. Under the first approach, the adverse impact of fixed costs on profitability results from industry overcapacity. ${ }^{57}$ This is inconvenient for the airlines, but is self-correcting over the long run: Over time, the airlines will reduce their capacity, bringing it in line with the scope of their operations and restoring their profitability. ${ }^{58}$ Indeed, that is the way competitive markets adjust capacity to demand.

The second approach assumes the airline industry to be one of a few industries that are structurally prone to so-called "destructive competition," 59 an affliction in which affected industries are said to operate for prolonged periods at a loss. ${ }^{60}$ Economic theories about destructive competition usually identify the affected industries as characterized by high-fixed costs and easy entry ${ }^{61}$ In fact, the avoidance of destructive competition was the rationale under which regulation was initially imposed on the trucking industry in 1935 and on the airline industry in $1938 .^{62}$ Current versions of the destructive competition approach make use of "core" theory: In a market of many sellers, high fixed costs, low marginal costs, and perishable (or non-storable) product, efficiency sometimes depends on cooperation among the players. ${ }^{63}$

Most economists currently reject the concept of destructive competition as a policy reason for according special treatment to an industry, unless a prolonged

56. See, e.g., Dempsey, supra note 46, at 460-61.

57. See Paul Stephen Dempsey, Airlines in Turbulence: Strategies for Survival, 23 TRANSP. L.J. *15, *25 (1995) (explaining empty seats caused by overcapacity drive down overall seat price because airlines want to cover some of their fixed cost).

58. See VASIGH, supra note 53.

59. Dempsey, supra note 57, at 85-89.

60. See Alfred E. Kahn, The Economics of Regulation: Principles and Institutions 172-76 (1971) (discussing “destructive competition”).

61. RABAH AMIR, Market Structure, Scale Economies and Industry Performance, 1, 26 (Nov. 2010), https://economics.indiana.edu/home/about-us/events/conferences-and-workshops/files/201103-04-01.pdf [https://perma.cc/MF5D-SBGC] (associating large fixed costs and easy entry with destructive competition).

62. See S. ReP. No. 75-1661, at 2 (1938) (urging immediate enactment of regulatory legislation over the airline industry in order "to prevent the spread of bad practices and of destructive and wasteful tactics resulting from the intense competition now existing within the aircarrier industry"); S. REP. NO. 74-482, at 2 (1935) (reporting motor carrier competition having been "carried to an extreme which tends to undermine the financial stability of the carriers and jeopardizes the maintenance of transportation facilities and service appropriate to the needs of commerce and required in the public interest").

63. See generally John Shepard Wiley, Jr., Antitrust and Core Theory, 54 U. CHI. L. REv. 556 (1987) (providing a background on core theory and the necessity of cooperation); for a more concise and recent treatment, see Dennis W. Carlton \& Jeffrey M. Perloff, Modern INDUSTRIAL ORGANIZATION (4th ed. 2005), https://wps.aw.com/aw_carltonper_modernio_4/ [https://perma.cc/9DG8-JLWQ]. 
period of unprofitability would jeopardize services that are essential to public welfare, such as (in the case of the airlines) neglecting safety precautions ${ }^{64}$ This, however, is a moot point because there is no evidence that the airlines are behaving in this manner. In fact, the large fixed-cost component in airline costs resembles many other industries. Many traditional industries, such as the steel and automobile industries, are characterized by high fixed costs. ${ }^{65}$ Even newer industries whose capital consists of intellectual property, such as the pharmaceutical and software industries are also characterized by high fixed costs. ${ }^{66}$ These industries all rely on the market to adjust capacity to demand.

Borenstein has suggested an explanation for poor industry performance that involves fixed costs, but one that takes account of interaction with other characteristics of the industry. ${ }^{67} \mathrm{He}$ argues that since regulation, there has been a great lack of certainty about viable business plans - a situation that has led to an emphasis on route expansion and overinvestment when times are good. ${ }^{68}$ This, combined with the instability of both demand and fuel cost, explains much of the varying but dismal profit performance of the industry. ${ }^{69}$ It is not necessary to criticize management's investment decisions to explain the industry's losses when the explanation is a temporary shrinkage of demand. The industry's investment in aircraft gives it the potential of earning enormous profits, as demonstrated in the current post-recessionary period. ${ }^{70}$ Management's investment decisions will be proven prescient or inadvisable by their long-term market effects.

2. Other Aspects of Industry Cost Structure.-Air travel has generated a rich literature on the determinants of costs. This has been made possible by copious data collection and reporting practices, much of it required by federal regulation, and has made U.S. airlines perhaps the most empirically studied industry in history. One major determinant of cost is the price of fuel, which has historically varied over time between eleven and thirty percent of total airline costs. ${ }^{71}$

64. See, e.g., George J. Benston, Savings Banking and the Public Interest, 4 J. Money, CREDIT, \& BANKING 133, 201-04 (1972) (arguing increased competition would not lead to destructive competition in the banking industry and increased competition with deregulation is, generally, in the public interest).

65. Henry Kallstrom, Investing in the Automotive Industry-What You Need to Know, MкT. REALIST (Feb. 5, 2015), http://marketrealist.com/2015/02/raw-materials-biggest-cost-driver-autoindustry/ [https://perma.cc/LZ2Z-DZXL].

66. Uwe E. Reinhardt, Perspectives on the Pharmaceutical Industry, 20 HEALTH AfF. 136, 144 (2001) ("Research-based pharmaceutical firms have high fixed costs (costs unrelated to the annual volume of production) and low variable costs (those that vary roughly proportionately with the volume of production).").

67. Borenstein \& Rose, supra note 33, at 33.

68. Id. at 34.

69. See Jad Mouawad, Airlines Reap Record Profits, and Passengers Get Peanuts, N.Y. Times (Feb. 6, 2016), http://www.nytimes.com/2016/02/07/business/energy-environment/airlinesreap-record-profits-and-passengers-get-peanuts.html [https://perma.cc/AWZ9-ER2U].

70. $I d$.

71. Borenstein \& Rose, supra note 33 , at 95. 
Another major determinant, holding all others factors constant, is called the "load factor," i.e., what percentage of a plane's total seats are filled. ${ }^{72}$ A number of route restructuring and data-intensive pricing practices have moved the average load factor from as low as fifty percent before deregulation to eighty-three percent by $2011 .^{73}$ Given that about eighty percent of a flight's costs are usually fixed, this was a major cost-saving development. ${ }^{74}$ Another important but intuitive finding is that longer flights are cheaper per passenger mile than shorter ones. ${ }^{75}$

Many industries exhibit important economies of scale; however, that concept applied to airlines must be approached with care. An influential study by Caves et al. distinguishes between economies of scale and economies of density. ${ }^{76}$ Economies of density result when, holding destinations constant, there are more flights, larger aircraft, or a denser seating arrangement-with the overall route structure and the load factor held constant. ${ }^{77}$ For example, (given a constant load factor) a denser seating arrangement or larger aircraft reduce cost per available seat mile. In those cases, more passengers are served by a less than proportionate outlay for pilots and crew, and by the same airport facilities. ${ }^{78}$ A critical difference between economies of density and economies of scale is that network structure is held constant when measuring economies of density. ${ }^{79}$ Economies of scale, by contrast, include possible additional declines in cost resulting from additional destinations.$^{80}$ Incremental economies of scale, however, affect average cost at a declining rate as the saving is allocated per seat mile; but economies of density achieved through denser seating affect each flight at the same rate on similar aircraft. ${ }^{81}$ Such definitions, while perhaps somewhat arbitrary, suggest the complexity of considering cost determinants in the industry. Much evidence suggests considerable economies from output based on density-about fifteen percent from a doubling of output-but little if any on an output expansion based

72. Airline Economics, AvJoBS, http://www.avjobs.com/history/airline-economics.asp [https://perma.cc/8ZLR-QCYJ] (describing the necessity of selling a fixed number of passenger seats) (last visited Jan. 19, 2017).

73. Load Factor (Passenger-Miles as a Proportion of Available Seat-Miles in Percent (\%)) All Carriers - All Airports, U.S.DEP'T TransP., http://www.transtats.bts.gov/Data_Elements.aspx? Data $=5$ [https://perma.cc/QR9U-B2EJ] (last visited Jan. 19, 2017).

74. Borenstein \& Rose, supra note 33, at 95.

75. Id. at 14 .

76. Douglas W. Caves et al., Economies of Density Versus Economies of Scale: Why Trunk and Local Service Airline Costs Differ, 15 RAND J. ECON. 471, 474 (1984).

77. Id.

78. VASIGH, supra note 53, at 125-26 (noting that as a given airline expands, the number of passengers carried from a specific airport and the average cost of that transport declines, because the costs of airport facilities are spread over more passengers; inversely, as the number of such passengers declines, the airline's average cost per passenger increases).

79. Caves et al., supra note 76.

80. Id.

81. Id. 
on the number of destinations without an increase in density. ${ }^{82}$ Moreover, unit costs have historically varied greatly among legacy carriers and not just between the legacies and the LCCs. ${ }^{83}$

The pattern of flights and plane changes has also been a source of cost saving. Borenstein cites the development of the hub-and-spoke system as one of the great, unanticipated developments of the post-regulation airline world. ${ }^{84}$ All of the legacy and many of the LCC carriers have found that considerable savings can be achieved by routing passengers through selected airports and combining them for flight continuation. ${ }^{85}$ The development of small regional jet aircraft accelerated this practice. The hub-and-spoke network is a major example of economies of density, achieved through consolidating operations. ${ }^{86}$

\section{E. Network Demand Effects}

Network effects is another industry characteristic that has been emphasized in recent discussions of public policy towards mergers in the industry, and its significance will be explored later in this Article. ${ }^{87}$ The airline industry and other transportation industries - like the telephone and other communications industries and also the software industry - generate network effects. In airlines, as in many other networks, there are "demand side economies of scale [that] arise whenever, as a network grows, it provides more than a proportional increase in its value to consumers. ${ }^{" 88}$ As noted, the hub-and-spoke structure of the legacy carriers generates network effects and is the source of significant efficiencies. ${ }^{89}$

\section{F. Overall Demand}

Although the demand for air travel has risen greatly over time as rising incomes have confronted stable or falling real prices-U.S. travel measured by revenue passenger miles quadrupled between 1978 and the turn of the twenty-first century, but demand has also varied with the business cycle, and from other shocks, already noted. ${ }^{90}$

The industry has always understood that business travelers have far more inelastic demand than does the rest of the travelling public ("leisure") travelers. ${ }^{91}$ The industry has exploited these differences in demand by the practice of offering higher-priced (e.g. business class) seating and lower-priced seating; and by

82. Borenstein \& Rose, supra note 33 , at 106-07.

83. Id.

84. Id. at 19.

85. Id.

86. Id. at 41 .

87. Id. at 5 .

88. John E. Kwoka, JR. \& Lawrence White, The Antitrust Revolution 520 (6th ed. 2014).

89. Borenstein \& Rose, supra note 33 , at 19.

90. Id. at 35 .

91. Id. at 15 . 
varying the ticket prices with the day of the week and the time of day; and also varying them as the time before takeoff approaches..$^{92}$ Indeed, the airlines exploit differing demands, much as utilities impose different charges to business customers than to residential customers. ${ }^{93}$

We have noted the hub-and-spoke structure's effect on reducing cost through economies of density. ${ }^{94}$ Now we consider the impact of the hub-and-spoke structure on demand. From its earliest development the hub-and-spoke system has created both costs and benefits for those based near hub airports. ${ }^{95}$ From a passenger's perspective, the greater choice of times and destinations (enhancing consumer welfare) has had to be set against the price premium that traditionally has attached to hub dominance (lowering consumer welfare), ${ }^{96}$ although that premium has declined substantially over recent years as result of LCC competition bolstered by computerized price shopping. Passengers, however, continue to show a marked preference for the airline offering the most service from an airport, holding all other characteristics of a flight constant. ${ }^{97}$ Besides the attractiveness of the service, this is also due to the successful use of marketing techniques, especially frequent flyer programs offering free tickets or other amenities, that introduce non-linear pricing ${ }^{98}$ into a purchaser's calculation and can create a principal-agent conflict for business travelers who may put personal benefit ahead of company savings. ${ }^{99}$ Loyalty discounts also exist for corporate purchasers based not on the volume of purchasing, but rather on the percentage of the firm's total air travel budget that is devoted to a certain airline. ${ }^{100}$ Cutting against the incumbency advantages of airport amenities and frequent flyer programs has been the growing role of computer-assisted price comparison and

92. Id. at 15-16.

93. See generally Frank P. Ramsey, A Contribution to the Theory of Taxation, 37 ECON. J. 47 (1927) (explaining the theory of exploiting demand to cover capital and other fixed charges). Exploiting demand is widely used by public utility regulators. See Daniel J. Gifford \& Robert T. Kudrle, The Law and Economics of Price Discrimination in Modern Economies: Time for Reconciliation?, 43 UC DAVIS L. REV. 1235, 1248 (2010).

94. Borenstein \& Rose, supra note 33 , at 41.

95. Id. at 19-20.

96. One commentator describes the hub (and associated spoke) as follows: "At hubs, we find a lot more nonstop service and relatively higher fares[.] . . . At spokes, we find very vigorous competition to carry passengers through competing hubs." Michael E. Levine, Antitrust Lessons from the Airline Industry: Airline Deregulation: A Perspective, 60 ANTITRUST L.J. 687, 693 (1991).

97. See Severin Borenstein, Trends: Pray for JetBlue, Milken Inst. Rev. 5, 11 (2014) (stating flyers prefer the airline that offers the most service out of passengers' home airport locations regardless of schedule, price, or onboard features).

98. In linear pricing, a purchaser pays a total amount for a purchase that is determined by price times quantity; any other pricing is nonlinear. Mark Armstrong \& John Vickers, Competitive Nonlinear Pricing and Bundling, 77 REv. ECON. StUD. 30, 30 (2010). Thus, a seller that is offering a quantity discount is engaged in nonlinear pricing.

99. Levine, supra note 96 , at 690-91.

100. Borenstein, supra note 97 , at 8 . 
purchasing. ${ }^{101}$ A recent survey suggests that nearly ninety percent of all travelers either sometimes or always use computer-assisted price comparisons before booking. ${ }^{102}$ In short, the airline industry shows a full range of demand effects, pricing behavior, and customer responses that would be expected in imperfectly competitive markets.

\section{G. How Do Airlines Compete?}

At the time of deregulation, many economists tended to view competition in the airline industry through the lens of William Baumol's theory of contestable markets. ${ }^{103}$ Under this theory, an industry behaves competitively if entry and exit into the market are costless. ${ }^{104}$ The airline industry was seen as a contestablemarket paradigm. ${ }^{105}$ It was relatively costless to move an aircraft from one location to another. ${ }^{106}$ Therefore, when any airline was able to raise its profits beyond a competitive return, those profits would attract entry that would compete them away. Because entry and exit were effectively costless, market power and sustained supracompetitive returns were impossible in the airline industry. ${ }^{107}$

In fact, entry and exit are not costless; new airline entrants must incur a set of pre-operating and "ramp-up" costs that are sunk (that is, nonrecoverable) in the event that the entrant leaves the market. ${ }^{108}$ The inapplicability of contestability theory is reflected in econometric studies that have shown that prices are higher

101. Fiona Scott Morton et al., Benefits of Preserving Consumers' Ability to Compare Airline Fares, CHARLES River Assocs. 6 (May 19, 2015), http://www.traveltech.org/wp-content/uploads/ 2015/05/CRA.TravelTech.Study_.pdf [https://perma.cc/7B32-QB28] (discussing that travelers would like to explore pricing and other options they have, although loyalty programs somewhat influence their decision); see also id. at 31-32 (discussing how an increase in the availability of metasearch engines increases competition among airlines).

102. See id. at 8 .

103. See Michael E. Levine, Airline Competition in Deregulated Markets: Theory, Firm Strategy, and Public Policy, 4 YALE J. ON Reg. 393, 403-04 (1987) (discussing role of contestable market theory during airline deregulation and recognizing theorists who applied contestability to the airline industry in the early 1980s); see also William J. Baumol, Contestable Markets: An Uprising in the Theory of Industry Structure, 72 Am. ECON. REV. 1, 1 (1982).

104. Baumol, supra note 103, at 3.

105. See, e.g., Elizabeth E. Bailey \& John C. Panzar, The Contestability of Airline Markets During the Transition to Deregulation, 44 LAW \& Contemp. Prob. 125 (1981) (applying contestable market theory to city-pair airline markets); see also Levine, supra note 103 (recognizing theorists who applied contestability to the airline industry in the early 1980s).

106. See Elizabeth E. Bailey \& William J. Baumol, Deregulation and the Theory of Contestable Markets, 1 YALE J. ON REG. 111, 128 (1984) (noting moving aircraft was easy).

107. See Bailey \& Panzar, supra note 105, at 125, 129 (noting airline prices were regulated by the possibility of competitors entering the market in 1979-1980 because the market was "almost perfectly contestable" and discussing how easy entry and exit into markets by new entities keep pricing competitive).

108. Levine, supra note 96 , at 60. 
when the number of competitors is lower and that the impact of potential competition alone, at least from legacy carriers, is modest. ${ }^{109}$ But one element of price competition has come through strongly in virtually all empirical work: the role of Southwest Airlines, which has had a moderating effect on prices after entry into a market has been announced or appears imminent, but before actual entry. ${ }^{110}$ Another emerging factor is the effect of JetBlue's market entry, in which entry of that carrier into city-pair markets has had a dramatic effect on prices. ${ }^{111}$

In sharp contrast to the "Southwest effect," 112 the impact of actual, not potential, competition from the legacy carriers may be modest. Brueckner and his colleagues, ${ }^{113}$ in a widely cited study, found that the reduction of legacy carriers on a route from three to two in 2008 led to virtually no price increase, while the same reduction led to an increase of four percent in 2000. Similarly, a consolidation from two to one carriers led to a price rise of twelve percent in 2000 but only $3.9 \%$ in $2008 .{ }^{114}$ Borenstein has interpreted the finding as suggesting that duopolies or even three-firm markets may already be engaged in full monopoly pricing. ${ }^{115}$ In light of the greatly increased level of concentration by mergers since $2010,{ }^{116}$ a reasonable inference is that price competition among the legacy airlines may now be very weak at best. Variations in fares certainly exist, but they are driven by complicated pricing models that combine a number of seats with various restrictions that form price "buckets" that change

109. Borenstein \& Rose, supra note 33, at 121.

110. See Jan K. Brueckner et Al., New Policy Issue: Network vs. LCC Competition AND Airfares: New EMPIRICAL Evidence from the U.S. 3 (2010), http://www.iata. org/publications/economic-briefings/Brueckner_Competition_Fares.pdf [perma.cc/TLS5-CT98] (showing the presence and potential entry of Southwest into a given market significantly lower fares in that market); see also Austan Goolsbee \& Chad Syverson, How Do Incumbents Respond to the Threat of Entry? Evidence from the Major Airlines 2, 17 (Nat'l Bureau of Econ. Research, Working Paper No. 11072, 2005), http://www.nber.org/papers/w1 1072.pdf[https://perma.cc/J7CWYBAD] (noting other airlines lower prices when Southwest announces opening a route but before it actually begins the route).

111. See Complaint at 800, United States v. US Airways Grp., Inc., 38 F. Supp. 3d 69 (D.D.C. 2014) (No. 1:13-cv-01236) (reciting the Boston-Washington D.C. fares dropped by $\$ 700$ when JetBlue entered that market).

112. Borenstein \& Rose, supra note 33, at 124 (pointing out the significance of the "Southwest effect" and Southwest's influence on airline markets).

113. BRUECKNER ET AL., supra note 110 , at 4.

114. Id. Ten years earlier, a Department of Justice study had found a ten percent average price effect in moving from three to two equally-sized participants in city-pair markets and discovered that a further move from two to one resulted in a twenty percent price increase. See Robert D. Willig, Antitrust Lessons from the Airline Industry: The DOJ Experience, 60 ANTITRUST L.J. 695, 701 (1991).

115. See Borenstein, supra note 97 , at 10 (pointing out monopoly-level pricing is used when two legacy carriers are on the same route).

116. Id. at 5 (discussing mergers after 2010 and stating the market share for the top four airlines increased from fifty-five percent as late as 2009 to seventy-one percent in 2014). 
substantially over time before a flight and increase the value of computer based fare comparisons. ${ }^{117}$

This does not mean that the legacy airlines do not compete, but like many other oligopolies, they appear to do so largely in dimensions other than price. ${ }^{118}$ In addition to frequent flyer programs and terminal amenities, legacy carriers have made onboard enhancements, such as offering in-flight entertainment systems on more domestic flights. ${ }^{119}$ (At the same time, of course, space per person, ${ }^{120}$ free food and drink offerings, and some free bag carriage in many legacy carriers have been shrinking. ${ }^{121}$ )

As noted previously, Borenstein concluded that constant experimentation with business models was one of the prime causes of industry profit instability and negative overall profit levels. This implies that the airlines have been uncertain about the strategies of their rivals, and this uncertainty would impede the tacit cooperation that would facilitate oligopoly pricing. Borenstein also concludes that overinvestment in good times in the quest for route expansion has played an important role in industry losses. ${ }^{122}$ The unprecedentedly high level of concentration recently achieved may have permanently dampened expansionary moves while facilitating pricing based on the recognition of mutual dependence. ${ }^{123}$ This tacit cooperation among the major airlines may remove the instability that has plagued the industry. Many industry observers have expressed

117. See Morton et al., supra note 101, at 19.

118. See Teresa Cederholm, The Airline Industry's Growth and Impact on Economic Prosperity, MкT. REALIST (Dec. 29, 2014), http://marketrealist.com/2014/12/bargaining-powerairline-industrys-customers-suppliers/ [http://perma.cc/9RDS-4HL9] (noting legacy carriers focus on providing extra features for flyers, while LCCs offer lower prices without such features); see also Felix Salmon, When Airlines Don't Compete, Reuters: U.S. Edition (Nov. 18, 2013), http://blogs.reuters.com/felix-salmon/2013/11/18/when-airlines-don't-compete/ [https://perma.cc/H3HC-TFQ5] (stating legacy carriers do not engage in price competition).

119. Grant Martin, Domestic In-Flight Entertainment Is Now Free on American, Delta and United, SKIFT (Aug. 15, 2016, 6:30 AM), https://skift.com/2016/08/15/domestic-in-flightentertainment-is-now-free-on-american-delta-and-united/ [https://perma.cc/8BNQ-2BYR].

120. See Charlie Leocha, How to Avoid Airline Seat "Densification” (You'll LUV This), ELLIOTT (Oct. 18, 2015), http://elliott.org/blog/how-to-avoid-airline-seat-densification-youll-luvthis/ [https://perma.cc/W7MH-V84N] (noting the trend of legacy carriers to reduce available seat space).

121. See C.S., Legacy vs. Low-Cost Carriers: Spot the Difference, ECONOMist: GulLiver Bus. TrAvel (Mar. 26, 2013), http://www.economist.com/blogs/gulliver/2013/03/legacy-vs-lowcost-carriers [https://perma.cc/772C-445R] (noting legacy carriers have engaged in cost-cutting strategies like adding baggage fees and cutting down on food offerings on short flights).

122. Borenstein, supra note 97 , at 6-7.

123. See Borenstein, supra note 42, at 235 (noting excessive expansion of some airlines can lead to lower pricing overall for airlines); see also Aaron Karp, Maintaining Capacity Discipline, AIR Transport World: AirKarP (Jan. 28, 2015), http://atwonline.com/blog/maintainingcapacity-discipline [https://perma.cc/JK5K-KLA7] (discussing current use of "capacity discipline" among major U.S. airlines). 
alarm at the failure of prices to decline with fuel in 2014 and 2015 and at the declarations by legacy CEOs of a need for capacity restraint. ${ }^{124}$

\section{H. Market Imperfections Connected with Airport Facilities: The Generation of Scarcity and Economic Rents}

Of the many features that distinguish airlines from other industries, publiclyowned facilities and politically-influenced decision making by an array of local and federal agencies stand out. U.S. airports are overwhelmingly controlled by public bodies, ${ }^{125}$ the air traffic control system lies entirely with the Federal Aviation Administration, and the highly obtrusive security system is operated by the Department of Homeland Security. ${ }^{126}$ Although airfares were deregulated and the rate-setting $\mathrm{CAB}$ was abolished, the Department of Transportation, as the successor to the $\mathrm{CAB},{ }^{127}$ retains a residual regulatory role over the aviation

124. Karp, supra note 4. According to news sources, the government is investigating a possible agreement among the carriers to limit capacity. Pete Williams \& Tom Costello, DOJ Looking into Possible Airline Collusion to Keep Fares High, NBC News (July 2, 2015), http://www.nbcnews. com/news/us-news/doj-looking-possible-airline-collusion-keep-fares-high-n385336 [https://perma.cc/Q4NQ-8JTJ]. There are, of course, major problems in any attempt to identify a capacity limitation agreement. Statements by airline officials warning against undue capacity expansion are indistinguishable from expressions of opinion. See Peter Coy \& David McLaughlin, What Does It Take to Prove Airline Collusion?, BloomBerg Bus. WK. (July 16, 2015, 7:00 AM), $\mathrm{http} / / /$ www.bloomberg.com/news/articles/2015-07-16/what-does-it-take-to-prove-airline-collusion[https://perma.cc/DY5D-YGQQ] (noting intentional communication is required to show an agreement existed). It is also the deployment of capacity on specific routes that creates problems for the airlines flying those routes, not aggregate capacity expansion, as the deployment can occur whether or not aggregate capacity is expanded. But marketing experimentation will continue. Delta, for example, is now trying to find a balance between the long-run yield of auctioning off business class upgrades and providing the upgrades to flyers with high accumulated mileage. See Justin Bachman, Airlines Really Don't Want to Upgrade People for Free, BloomBERG: PURSUITS (Mar. 4, 2016), http://www.bloomberg.com/news/articles/2016-03-04/airlines-really-don-t-want-toupgrade-people-for-free [https://perma.cc/9WB9-8W69] (noting Delta plans to charge more for seat upgrades rather than giving upgrades for free); see also Airlines Auction Seat Upgrades, MONEYTIPS (Aug. 12, 2016), http://www.moneytips.com/airlines-auctioning-upgrades [https:// perma.cc/U77B-MXJ9] (noting Delta has run test auctions on seat upgrades).

125. Under the Airport Improvement Act of 1982, 49 U.S.C. $\S \S 47101-47134$ (2012), generally only publicly-owned airports are eligible for funding under the Airport Improvement Program. See 49 U.S.C. $\S \S 47102$ (18) and (26) (2012) (defining grants as money being given to "sponsors" and defining "sponsors" as including public or public-use airports); see also National Policy: Airport Improvement Program Handbook, FAA DOT, Order No. 5100.38D (2014) https://www.faa.gov/airports/aip/aip_handbook/media/AIP-Handbook-Order-5100-38D.pdf [https://perma.cc/R7HF-D4Q6] (clarifying only public agencies and public-use airports are eligible to be sponsors for Airport Improvement Program grants).

126. Borenstein \& Rose, supra note 33, at 124.

127. See CAB Sunset Act of 1984, Pub. L. No. 98-443, 98 Stat. 1703 (1984) (transferring 
system that extends to control over the economic fitness of airline entrants and consumer protection activities. ${ }^{128}$ Its role may also extend to competitive considerations (other than enforcement of the merger provision of section seven of the Clayton Act) affecting the airlines. ${ }^{129}$ The infrastructure of the air transport system is funded by a combination of local and federal monies, some of which come from airport use charges and from bond issues. ${ }^{130}$ Congressional legislation has often stipulated conditions for new federal support. ${ }^{131}$ The bonds have sometimes been purchased by airlines, ${ }^{132}$ which can then enable them to exercise influence ("majority-in-interest") over airport expansion activity that could facilitate entry. ${ }^{133}$

Although most airports are not congested most of the time, ${ }^{134}$ certain key airports such as Chicago's O'Hare; the three airports serving New York (LaGuardia, Kennedy, and Newark); ${ }^{135}$ Atlanta; ${ }^{136}$ and Los Angeles experience substantial congestion. ${ }^{137}$ The growth of air traffic is bound to increase congestion

regulation authority from the $\mathrm{CAB}$ to the Department of Transportation).

128. See U.S. Gov't Accountability Off., RCED-89-93, Airline Competition: DOT's IMPLEMENTATION OF AIRLINE REgULATORY AUTHORITY (1989), http://www.gao.gov/products/ RCED-89-93 [https://perma.cc/XV7K-PPXW] (evaluating the consumer protection function of the Department of Transportation); see also 49 U.S.C. § 41108 (2012) (granting Secretary of Transportation authority to make decisions on applications for certificates required to operate airline carriers).

129. See, e.g., 49 U.S.C. $\$ 41101$ (2012) (setting forth requirement for airline carriers to obtain certificates to operate); $i d$. $\S 41712$ (discussing "unfair and deceptive practices and unfair methods of competition").

130. Airport Financing, AIRPORTS COUNCIL INT'L - N. AM., http://www.acina.org/content/airport-financing [https://perma.cc/A5YS-NAQS] (last visited Jan. 19, 2017).

131. See FAA Airport Compliance Manual, FAA Order No. 5190.6B, at 15-1, 15-3 (Sept. 30, 2009), https://www.faa.gov/documentLibrary/media/Order/5190_6b.pdf [https://perma. cc/9XYD-ZYRT] (listing several federal acts placing restrictions on airports that receive federal funding).

132. See Airport Business Practices and their Impact on Airline Competition, DeP'T of TransP., at viii (Oct. 1999), http://ntl.bts.gov/lib/17000/17100/17129/PB2000108301.pdf [https://perma.cc/2PBB-GRAH] (noting purchase of bonds can lead to more protection in airline agreements).

133. See Morton et al., supra note 101, at 43 (discussing how some airline agreements contain "majority-in-interest" provisions, which grant airlines more power in airport projects and decisions).

134. Michael E. Levine, Airport Congestion: When Theory Meets Reality, 26 YALE J. On REG. 37, 41-42 (2009).

135. Id. at 53,56 .

136. Thanksgiving in the Skies: A Look at the Future of Air Travel in America, U.S. TRAVEL Ass'N 1, 10 (2014), https://www.ustravel.org/sites/default/files/Media\%20Root/Thx_report_ single_page.pdf [https://perma.cc/NF6R-MH2Z] (listing Atlanta as one of the airports that will continue to have capacity problems even after the airport makes additions).

137. Editorial Bd., LAX Congestion Demands Regional Solutions, L.A. DAILY NEWs (July 29, 
over the long term. Although expansion and new construction are underway at several major airports, ${ }^{138}$ only one new major airport (in Denver) has been constructed in over two decades. ${ }^{139}$

The disposition of limited gate space and the use of airspace at certain times (slots) have typically been handled by various administrative rules favoring incumbency. ${ }^{140}$ Gates are commonly leased to airlines under exclusive long-term leases. ${ }^{141}$ Although the leasing airline sometimes subleases to other carriers for short-terms, this arrangement keeps ultimate control in the hands of the long-term lessee. At airports where a single airline generates more than fifty percent of the passenger volume, federal law requires submission of a plan to increase competition in order for the airport to be eligible for federal financial aid for expansion. ${ }^{142}$ Although Congress intended this legislation to foster competition, it sometimes creates the opposite effect. Both gates and slots are often successfully hoarded by incumbents to impede entry. ${ }^{143}$ Moreover, general aviation (small private planes) are allowed to clog facilities through the use of fees that do not reflect their negative externalities. ${ }^{144}$ Additionally, flights from small cities have uneconomic access to major airports in response to political pressure, and the air travel control system staffed by FAA employees has lagged badly in technology compared to privatized systems in other countries. ${ }^{145}$ The Department of Transportation relies on advice from the Department of Justice on the competitive impact of slot transfers, but this sometimes only keeps a bad

2015, 6:30 PM), http://www.dailynews.com/opinion/20150729/lax-congestion-demands-regionalsolutions [https://perma.cc/EX8U-YYHD].

138. Atlanta is adding twelve new gates, Los Angeles is adding eighteen gates, and Houston is adding five gates. Jad Mouawad, Airports Focus on the Ground, N.Y. TimES (June 15, 2012), http://www.nytimes.com/2012/06/15/business/building-boom-takes-hold-at-us-airports.html [https://perma.cc/Y56Z-6QF5].

139. Id.

140. See generally The Antitrust Implications of Airport Lease Restrictions, 104 HARV. L. REV. 548, 557-58 (1990) (describing majority-in-interest clauses make entry difficult because entrants are forced to sublease gate space from incumbents at high prices).

141. Id. at 551 .

142. 49 U.S.C. § 47106(f) (2012); see also John Sabel, Airport Facilities Agreements: An Overview, 69 J. AIR L. \& COM. 769, 786 (2004) (explaining the competition plan requirement).

143. See generally Gregory M. Seigel, Attention Passengers: Your Flight Will Be Delayed - Congestion Pricing as a Solution to Airport Traffic Management, 39 TRANSP. L.J. 165, 177 (2012) (detailing how new airlines had trouble getting slots under the High Density Rule because incumbents hoarded them).

144. See generally J. David Grizzle et al., Navigating the Turbulence of Competing Interests: Principles and Practice of the Federal Aviation Administration, 75 J. AIR L. \& COM. 777, 784, 803 (2010) (noting the competition for space, which leads to the negative externality of delay).

145. Scott McCartney, The Air-Traffic System U.S. Airlines Wish They Had, Wall St. J. (Apr. 27, 2016, 5:51 PM), http://www.wsj.com/articles/the-air-traffic-system-u-s-airlines-wish-they-had1461776053 [https://perma.cc/2KD3-DPHJ]. 
situation from getting worse. ${ }^{146}$ To the extent that these administrative arrangements impede entry or expansion, they generate economic rents, advantaging the dominant airlines, and likely account for significant portions of the so-called "hub price premium." Williams found that gate control at congested airports is a key element of the hub price premium. ${ }^{148}$

\section{Government Supervision of Mergers and Competition}

From deregulation in 1978, supervision over airline mergers initially remained in the $\mathrm{CAB} .{ }^{149}$ The end of the $\mathrm{CAB}$ came on January 1, 1985, with supervision over airline mergers passing to the DOT where it remained until the end of $1988 .{ }^{150}$ Congress divested the DOT's antitrust authority over airline industry mergers and gave it to the DOJ in hopes of greater enforcement against anticompetitive airline mergers. ${ }^{151}$ The DOT, however, retained authority (formerly administered by the $\mathrm{CAB}$ ) to halt "unfair or deceptive practice[s] or unfair method[s] of competition. ..."152 This authority was contained in section 411 of the Federal Aviation Act, ${ }^{153}$ which was closely modeled after section five of the Federal Trade Commission Act (FTCA). Section 411 of the Federal Aviation Act has been renumbered and reenacted as 49 U.S.C. $\S 41712$, but this Article follows common usage in the airline industry by continuing to refer to the provision as section 411. Just as the Federal Trade Commission asserts power to

146. See e.g., Ken Heyer \& Carl Shapiro, The Year in Review: Economics at the Antitrust Division, 2009-2010, 37 REv. INDUS. ORG. 291, 304-06 (2010).

147. See generally Justin Bachman, Forget About Airline Mergers. Now It's All About Trading Airport Slots, Bloomberg (June 16, 2015, 4:48 PM), http://www.bloomberg.com/news/ articles/2015-06-16/forget-about-airline-mergers-now-it-s-all-about-trading-airport-slots [https://perma.cc/255Q-JY3U] (noting airlines are swapping slots to boost profits at hubs).

148. Federico Ciliberto \& Jonathan W. Williams, Limited Access to Airport Facilities and Market Power in the Airline Industry, 53 J. L. \& ECON. 467, 485-86 (2010).

149. Paul Stephen Dempsey, Transportation: A Legal History, 30 TrANSP. L.J. 235, 339-40 (2003).

150. Id.

151. Alberto G. Rossi, Grounding Future Consolidations: United-US Airways Cancel Flight, 54 Admin. L. Rev. 883, 886 (2002). The CAB Sunset Act of 1984, Pub. L. No. 98-444, 98 Stat. 1704 vested the Department of Transportation (as the successor to the CAB) with supervision over airline mergers until the end of 1988. At that time, merger supervision became the responsibility of the Department of Justice. The merger approvals of the Department of Transportation have been subject to criticism, for example Senate Commerce Committee Chairman Eernest F. Hollings (DS.C.) said: "Merger after merger has been approved (by the Transportation Department), including those opposed on legitimate competitive reasons by the Justice Department[.]" Transportation Official Defends Airline Merger, LA Times (Nov. 5, 1987), http://articles.latimes.com/1987-1105/business/fi-18968_1_airline-mergers [https://perma.cc/N3E9-QAPU].

152. 49 U.S.C. $\S 41712$ (1994).

153. Id. 
prohibit anti-competitive behavior beyond the reach of the Sherman and Clayton Acts under section five of the FTCA,${ }^{154}$ the DOT asserts power to prohibit such behavior beyond the reach of the Sherman and Clayton Acts under section 411 . It asserts that power despite Congress having explicitly transferred its enforcement authority under section seven of the Clayton Act to the DOJ.

\section{Three Phases of Antitrust Activity}

\section{A. The Market Magic Phase}

The theory of market contestability, already noted, provided part of the impetus for the 1978 deregulation and much of the related intellectual atmosphere for the next several years. ${ }^{155}$ The optimism of the deregulators matched that of entrepreneurs. Entry was dramatic but often short-lived. Although there were about a dozen each long distance and local jet carriers at the dawn of deregulation, forty-seven entrants joined them by $1984 .{ }^{156}$ Of those that entered, only seven were still operating in $1990 .{ }^{157}$ Another cycle of entry arose in the mid-1990s when eighteen new carriers entered, but once again, most of the entrants ultimately disappeared. ${ }^{158}$ These recurring cycles of entry and exit are consistent with the volatility of the airline passenger market.

Contestability as an assurance of competitive behavior turns on three crucial assumptions: New firms have the same technology, prices, costs, and information as incumbents; there are zero sunk costs; and the lag between incumbent knowledge of entry and entrant's new supply is less than the lag of price response by incumbent firms. ${ }^{159}$ In the airline industry, some new carriers often had lower costs than the incumbents, which have traditionally been saddled with high labor costs due largely to union entrenchment under regulation. ${ }^{160}$ The other two

154. 15 U.S.C. $\$ 45$ (1994). In its recent case against Intel Corp., the FTC invoked both section 2 of the Sherman Act and section 5 of the FTCA. Commissioner J. Thomas Rosch would have had the Commission rely exclusively on section 5. See In re Intel, Docket No. 9341 (Dec. 16, 2009) (Rosch, concurring and dissenting). Section 5 is the Commission's "stand alone" authority. See John Graubert \& Jesse Gurman, The FTC/Intel Settlement: One Step Forward, One Step Back?, 25 Antitrust *8, *9 (2011). It is unclear how far this "stand alone" authority extends. See, e.g., E.I. Du Pont de Nemours \& Co. v. FTC, 729 F.2d 128, 139-42 (2d Cir. 1984).

155. See Dempsey, supra note 35 , at 713 (explaining how proponents of deregulation thought contestability theory pertained to the airline industry).

156. Borenstein \& Rose, supra note 33 at 87.

157. Id. at 88 .

158. Id. at 88 .

159. W. Kip Viscusi et al., Economics of Regulation and Antitrust 172-73 (4th ed. 2005).

160. See generally Terry Maxon, American Airlines Says It Needs Labor Cuts to Survive; Unions Disagree, DALL. NEws (Apr. 2012), http://www.dallasnews.com/business/airlines/ 2012/04/23/american-airlines-says-it-needs-labor-cuts-to-survive-unions-disagree [https://perma.cc/QR7J-ESNR] (noting American Airlines has very high wages and seeks to reduce 
conditions also raise doubts about the relevance of the approach: Sunk costs may be low but they are not negligible, and incumbents will know of entry long enough in advance to mount an immediate response upon entry. The most successful entrant, Southwest, misses the contestability paradigm entirely. It maintained a considerably lower cost of production than the legacy carriers until recently. ${ }^{161}$ It developed a reputation for a dependable and high quality, if somewhat Spartan product. Southwest also avoided head-on attacks against the legacies, preferring an approach of attrition. ${ }^{162}$ In doing the latter, it discouraged predatory price attacks. Southwest's impact on markets, where it was thought likely to enter, is consistent with "limit pricing," a much older model of pricing than contestability.

Throughout this whole period-before, during, and after the high tide of belief in airline-market contestability-Alfred Kahn, the father of deregulation, maintained a strong belief in vigorous antitrust enforcement. ${ }^{163} \mathrm{Kahn}$ did not view contestability as reducing the need for antitrust. ${ }^{164}$ Rather, he believed the deregulated airline industry needed conventional antitrust remedies, especially in regard to predatory pricing by incumbent firms ${ }^{165}$ and increased concentration from uncontrolled mergers. In 1987, he wrote critically of the DOT's laissez-faire policies and its failure to use its antitrust authority to block anticompetitive airline mergers: "[I]f contestability were perfect, there would be no need for antitrust laws at all... That is very close to the position the Department of Transportation has in effect taken in blithely dismissing objections by the Department of Justice to the Northwest-Republic and TW A-Ozark mergers. ..."166 Merger studies from 1985-1988, when the DOT was the merger enforcement authority, support Kahn's view that the DOT was over-tolerant of airline merger activity. ${ }^{167}$ Considering the

labor costs).

161. Justin Bachman, Southwest CEO's Cost Crusade: Haggling with Unions While Profits Soar, BloOMBERG (Sept. 27, 2014, 5:52 AM), http://www.bloomberg.com/news/articles/2014-0917/southwest-airlines-plan-to-keep-costs-low-saying-no-to-pay-raises [https://perma.cc/ETR3ULLS].

162. See generally Shawn Tully, Southwest Bets Big on Business Travelers, ForTUNE (Sept. 23, 2015, 11:00 AM), http://fortune.com/2015/09/23/southwest-airlines-business-travel/ [https:// perma.cc/8CAC-MMXX] (explaining how Southwest flew to small markets to avoid legacies).

163. See generally Joseph B. White, Airline Mergers: What the Father of Deregulation Might Say, WALL ST. J. (Feb. 12, 2013, 1:35 PM), http://blogs.wsj.com/corporate-intelligence/2013/02/ 12/a-u-s-airline-industry-big-four-what-alfred-kahn-might-say/ [https://perma.cc/XS98-P2UN] (explaining Kahn's belief that antitrust regulators needed to stop airlines from gaining too much control over well-traveled and important routes).

164. $I d$.

165. See Alfred E. Kahn, Deregulatory Schizophrenia, 75 CAL. L. Rev. 1059, 1067 (1987) (citing A. Kahn, Towards a Policy for Dealing with Competitive Responses 1-4 (Oct. 19, 1978) (unpublished manuscript) (on file with the California Law Review)).

166. Id. at 1062 .

167. See generally E. Han Kim \& Vijay Singal, Mergers and Market Power: Evidence from the Airline Industry, 83 AM. ECON. REv. 549, 550 (1993) (detailing how the government did not 
fourteen mergers over the period in question, one such study found price increases by the merging firms on affected routes of $9.44 \%$ relative to unaffected routes. ${ }^{168}$ Other firms on these routes saw an increase of over twelve percent. ${ }^{169}$ This result was consistent with increasing concentration leading to a higher level of recognized mutual dependence. On the issue of predatory behavior, the DOT eventually moved in Kahn's direction, proposing its own policies to counter predatory or predatory-like behavior of major carriers. ${ }^{170}$

\section{B. The Vigorous Antitrust Phase}

There were few mergers approved over the following twenty years, and those that were usually "involved at least one airline that was in extreme financial distress." $" 171$ The DOJ opposed the proposed acquisition of US Airways by United, announced in 1999, and it was withdrawn because: (1) both carriers had hubs in the Washington D.C. area, which would monopolize service to some cities; (2) they dominated several hub-hub markets; (3) they were two of the three main airlines serving small Northeast cities, and the merger would significantly increase concentration in eastern cities; and (4) competition would be reduced on several transatlantic markets. ${ }^{172}$ The DOJ later contrasted its negative judgment on this transaction with its approval of America West/US Air merger. ${ }^{173}$ The latter was described as a geographic "barbell," (i.e., largely non-overlapping networks) that was held up as "an example of the kinds of mergers that may easily avoid antitrust problems." $" 174$

What of Fred Kahn's other concern: predatory behavior? The basic rules of that analysis are set out in the Supreme Court's 1993 Brooke Group decision. ${ }^{175}$ The Brooke Group predation standard requires sales below an appropriate

contest mergers, which led to increased airfare), http://webuser.bus.umich.edu/ehkim/articles/ mergersmarkets-aer1993.pdf [https://perma.cc/6245-SFZJ].

168. Id. at 550 .

169. Id.

170. Department of Transportation Proposal, Unfair Exclusionary Conduct in Air Transportation Industry, Trade Reg. Rep. (CCH) 『 50, 163 (1998).

171. Borenstein \& Rose, supra note 33, at 20.

172. J. Bruce McDonald, Deputy Assistant Attorney Gen., U.S. Dep't of Just., Antitrust for Airlines (Nov. 3, 2005), http://www.justice.gov/atr/speech/antitrust-airlines [https://perma.cc/ YNU8-5L44].

173. Id.

174. Id. Beginning in the 1988 s, the airlines began a generally uncontroversial practice of codesharing, which increased the ease with which a passenger could move across a route involving more than one airline. The passenger need get only one ticket to travel with two carriers. This involved an agreement between carriers that assigned with sale of the entire ticket by one airline at a price that it determined, while the other carrier was reimbursed at estimated operating cost. The practice appeared to eliminate the usual inefficient double marginalization of vertical arm's length sales without the need for integration.

175. Brooke Grp. v. Brown \& Williamson Tobacco Corp., 509 U.S. 209 (1993). 
measure of cost and a likelihood of recoupment. ${ }^{176}$ Along with the Brooke Group's formulation, the lower courts generally apply the standards worked out in the 1970s by Donald Turner and Philip Areeda (the Areeda-Turner standard), which is consistent with the Brooke Group standard but is somewhat more precise, recommending the use of average variable cost as the effective boundary between predatory and non-predatory pricing. ${ }^{177}$

In 1999, the DOJ filed suit against American Airlines for predatory behavior towards LCCs, Vanguard, Western Pacific, and Sunjet on three routes connecting Dallas-Fort Worth with Wichita, Colorado Springs, and Long Beach. ${ }^{178}$ The problems of applying previous standards to airline competition became immediately apparent. ${ }^{179}$ The court attempted, as far as possible, to follow the scheme established in Brooke Group: establishing that (1) the incumbent would have market power without the additional competition provided by the LCCs, (2) American engaged in pricing below some appropriate measure of its costs, and (3) there was a "dangerous probability" of subsequent recoupment of losses incurred during the predatory period. ${ }^{180}$ American Airlines lowered its prices to match those of the LCCs, claiming that these price reductions were simply meeting the competition. ${ }^{181}$ Although the DOJ argued that American's increased capacity on the contested routes greatly diluted demand for the newcomers' similarly priced product-a Section 2 violation, independent of predatory pricing - the courts did not accept the argument. ${ }^{182}$ There were complicated and inconclusive attempts by both sides to establish whether or not American actually did price below the usually accepted average variable cost standard. ${ }^{183}$ Although the district and circuit courts left the appropriate standard unresolved because the DOJ's cost estimates were rejected, ${ }^{184}$ the circuit court did recognize that the appropriate cost figures should be based only on additional capacity brought to the route as part of the alleged predation. ${ }^{185}$ Finally, the circuit court did not reject the DOJ's contention that predatory pricing in one venue need not result in recoupment there alone but instead could plausibly have broader profitable impact pour encourager les autres. ${ }^{186}$

176. Id. at 225-27.

177. Phillip E. Areeda \& Donald F. Turner, Predatory Pricing and Related Practices Under Section 2 of the Sherman Act, 88 HARV. L. REV. 697, 716-18 (1975).

178. See United States v. AMR Corp., 335 F.3d 1109, 1111 n.1, 1112 (10th Cir. 2003).

179. Id. at 1114-15.

180. Id. at $1114-17$.

181. Id. at 1112 .

182. Id. at $1111,1120-21$.

183. Id. at $1116-20$.

184. Id.

185. Id. at 1119 .

186. Id. at 1115; see also Gregory J. Werden, The American Airlines Decision: Not with a Bang but a Whimper, 18 ANTITRUST 32 (2003) (discussing the "pragmatic" approach taken by the Tenth Circuit, accepting the government's argument in favor of analyzing costs and revenue of incremental capacity additions rather than the system-wide analysis required by Brooke Group; the 
In 2000, Spirit Airlines sued Northwest Airlines for violating Section 2 of the Sherman Act. ${ }^{187}$ Once again, the pattern involved lowering prices toward those of the entrant while greatly increasing capacity, effectively thinning demand for the entrant's offering. ${ }^{188}$ This was followed by a sharp increase in prices after the LCC's withdrawal. ${ }^{189}$ Spirit constructed a case that did not involve recoupment beyond the Detroit airport. ${ }^{190}$ Instead, it argued that delays in new entry alone would have made Northwest's price and capacity changes profitable. ${ }^{191}$ Although Spirit's case was rejected by the district court's summary judgment, the Sixth Circuit remanded the case for full trial. ${ }^{192}$ That same year, 2005, Northwest filed for bankruptcy and Spirit dropped the case. ${ }^{193}$

Continuing complaints by would-be successful entrants into the industry as well as consumer groups about predation towards start-ups generated attention by the DOT, which issued a proposed approach to predation tailored especially to the airline industry based on a legal framework different from the one developed by the courts. ${ }^{194}$ The DOT proposal simply ignored prevailing precedent (most notably Brooke Group), bypassing consideration of the price/cost relation entirely. ${ }^{195}$ Instead the test would simply be whether a capacity expansion costs the dominant firm (1) more revenue than the entrant would have diverted from it or (2) more than the result of either matching the entrant's fares or establishing the same relative fares as with better established entrants elsewhere. ${ }^{196}$ Although the DOT's proposal was based on its authority under section 411 to prevent unfair or deceptive practices or unfair methods of competition, it did not fare well. ${ }^{197}$ Congress responded to the Department's proposal by mandating a study by the National Council's Transportation Research Board (TRB) which failed to endorse the DOT's policy. ${ }^{198}$ A GAO report describing the DOT's proposal noted that several airlines had criticized the proposal's language as vague, and that the DOT

court also decided the issue rather than remand it, "[a] trial was unlikely to elicit much evidence not already in the extensive summary judgment record" and would only "delay the inevitable").

187. See Spirit Airlines, Inc. v. Northwest Airlines, Inc., 431 F.3d 917 (6th Cir. 2004).

188. Id. at 921-24.

189. Id. at 924 .

190. Id. at $924-25,928-30$.

191. Id. at $928-30$.

192. Id. at 921,953 .

193. Id. at 921 n.1; see also Kenneth G. Elzinga \& David E. Mills., Predatory Pricing in the Airline Industry: Spirit Airlines v. Northwest Airlines, in 6 THE ANTITRUST REVOLUTION 307 (John E. Kwoka, Jr. \& Lawrence J. White eds., 2014).

194. Enforcement Policy Regarding Unfair Exclusionary Conduct in the Air Transportation Industry, 63 Fed. Reg. 17, 919 (proposed Apr. 10, 1998).

195. Off. of the Secretary, U.S. DOT, Docket OST-98-3713, Enforcement Policy Regarding Unfair Exclusionary Conduct in the Air Transportation Industry: Findings and Conclusions on the Economic, Policy, and Legal Issues 70-72 (2001).

196. Id. at 16-17.

197. Id. at $9-12$.

198. Id. at $2-4,8$. 
was planning on refining its terminology in response. ${ }^{199}$ Finally, in January 2001 , the DOT decided to address predatory behavior in fact-specific adjudications under section $411 .^{200}$

In the comments on the DOT proposal, the major airlines argued that it was proper for them to match an entrant's low fares on a large number of seats, ${ }^{201} \mathrm{a}$ proposition rejected by the DOT. The major airline position also describes the behavior of American in the suit brought by the DOJ, where American matched the fares of Vanguard, Western Pacific, and Sunjet on routes out of Dallas-Fort Worth and added seating capacity. ${ }^{202}$ The major airlines' position thus appears to be based upon the Supreme Court's Brooke Group opinion, read as condemning predatory pricing defined as below-cost pricing combined with a likelihood of recoupment and as accepting the lawfulness of pricing and related behaviors that do not fall within that definition. ${ }^{203}$ The airlines' reading of Brooke Group may also be supported by the Court's assertion in that case that evaluating pricing above a relevant measure of cost may be "beyond the practical ability of a judicial tribunal to control without courting intolerable risks of chilling legitimate pricecutting. ${ }^{204}$ In American Airlines, the government failed to show that American's incremental revenues on the flights in question fell below either its average variable cost or its average avoidable cost. ${ }^{205}$ The government-DOT and the DOJ-had been searching for an alternative to a strict reading of Brooke Group. ${ }^{206}$ It has found limited support among scholars but not in the courts or elsewhere. ${ }^{207}$

Overall, the government was left in a quandary in the early years of this century. The DOT was unable to implement its new approach to predation, and the DOJ was unable to persuade the court that capacity additions could be treated as predatory behavior, or establish below-cost pricing under the classic Brooke

199. U.S. Gov't Accountability OfF., GAO/RCED-99-225, Aviation Competition: Information on the Department of Transportation's Proposed Policy, Report to the Chairman, Committee on the Budget, House of Representatives 2, 14 (1999).

200. Off. of the Secretary, supra note 195, at 98-113 (discussing full legal justification provided by DOT).

201. Id. at 45-52 (describing comments of network airlines and DOT's assessments of those responses).

202. United States v. AMR Corp., 335 F.3d 1109, 1112 (10th Cir. 2003).

203. Off. of the Secretary, supra note 195, at 12-13.

204. Brooke Grp. v. Brown \& Williamson Tobacco Corp., 509 U.S. 209, 223 (1993).

205. The government urged the court to accept an alternative to average variable cost for evaluating the case before it. AMR Corp., 335 F.3d at 1116. The court used both average variable cost (AVC) and average avoidable cost. Id. at 1120. Average avoidable cost had earlier been proposed as a substitute for AVC by William Baumol. See William J. Baumol, Predation and the Logic of the Average Variable Cost Test, 39 J. L. \& ECON. 49 (1996).

206. Off. of the Secretary, supra note 195.

207. See Aaron S. Edlin, Stopping Above-Cost Predatory Pricing, 111 YALE L.J. 941 (2002). See also Einer Elhauge, Why Above-Cost Price Cuts to Drive Out Entrants Are Not Predatory - and the Implications for Defining Costs and Market Power, 112 YALE L.J. 681 (2003). 
Group standards. ${ }^{208}$

\section{The Recent Merger Approvals}

As noted earlier, the post-2008 crisis period has seen four major mergers approved by the DOJ, producing a significant cumulative increase in concentration. ${ }^{209}$ In a recent merger (American/US Air) the DOJ's brief listed 460 city-pair markets which the guidelines would treat as presumptively unlawful on concentration grounds. ${ }^{210}$ It is important, therefore, to examine the DOJ's approach to these mergers and the rationales that it employed in approving them. How is it that the DOJ initially sought to enjoin the American/US Air merger but subsequently approved it?

Given the troubled financial history of the airline industry, this Article first examines the failing firm doctrine to ascertain whether that doctrine offers any basis for the merger approvals. ${ }^{211}$ The Article concludes that it does not. ${ }^{212}$ This Article then examines potential competition. ${ }^{213}$ Would potential competition among the legacy carriers prevent the DOJ from approving these mergers? The Article concludes that the DOJ did not consider the other legacy carriers as potential competitors and only took into account actual competition between the merging airlines. ${ }^{214}$ This Article also examines network effects, observing their potential to generate consumer benefits. ${ }^{215}$ The Article concludes that the DOJ's approval aimed at the generation of consumer benefit that would result from each merger's combination of the parties' networks. ${ }^{216}$ Underlying and supporting this analysis are (1) the minimal anticipated price effects of the mergers, probably due largely to the competition of the LCCs; and (2) the opportunities provided by two of the mergers for the DOJ to condition approval upon transfer of legacy-held gates and slots to LCCs. ${ }^{217}$

1. The Failing Firm Defense.-Antitrust law does not recognize a "failing firm" defense to an otherwise unlaw ful conditional merger unless (in the absence of the merger) the assets of one of the merging firms would exit the market. ${ }^{218}$ Under both the merger guidelines and the case law, this requires a showing that firm in question is unable to reorganize under Chapter 11 of the Bankruptcy

208. AMR Corp., 335 F.3d at 1118-21.

209. See Horizontal Merger Guidelines, infra note 228, at $18 \mathrm{n} .9$

210. Complaint at Appendix A, United States v. US Airways Grp., Inc., 38 F. Supp. 3d 69 (D.D.C. 2014) (No. 1:13-cv-01236).

211. See infra notes $219-20$ and accompanying text.

212. See id.

213. See infra notes 221-35 and accompanying text.

214. See id.

215. See infra notes 236-76.

216. See id.

217. See id.

218. See, e.g., FTC v. Arch Coal, Inc., 329 F. Supp. 2d 109, 153-54 (D.D.C. 2004). 
Act. ${ }^{219}$ In fact, reorganization under Chapter 11 is common in the airline industry where such reorganizations have enabled legacy carriers to cancel or modify labor contracts and thereby to reduce their labor costs. ${ }^{220}$ So Chapter 11 was clearly available to the merging airlines and many of the merging parties had recently used it. The merging firms thus did not meet the preconditions for using the failing-firm defense.

2. Potential Competition.-One seemingly obvious objection to the merger of two airlines, even where route overlap is not substantial, turns on potential competition. ${ }^{221}$ That is, how likely is it that, in the absence of the merger undergoing review, one merger partner would choose to enter a city-pair market to compete with the other merger partner? ${ }^{222}$ In none of the merger evaluations did the DOJ consider the potential competition that one of the merger partners posed for the other, absent the merger.

In 2005, an Antitrust Division official described its merger enforcement approach to the airline industry as:

Reviewing any particular merger, we first identify the city pairs in which the merging carriers both provide service. It also may be appropriate to consider markets in which the two both are likely to provide service in the future, such that today they are 'potential' competitors. ${ }^{223}$

How the likelihood of entry would be evaluated goes unstated. Nevertheless, despite the varying strengths of the firms involved in the recent mergers, all were in some sense national firms with at least some potential to increase their presence in geographic areas in which they were relatively weak. ${ }^{224}$

Discussion of mergers between firms that might become direct competitors has changed across the various versions of the Merger Guidelines. The 1984 Merger Guidelines treated mergers involving potential competitors as nonhorizontal mergers, which were distinguished from vertical and horizontal mergers. ${ }^{225}$ Under the 1984 Merger Guidelines, mergers involving potential competitors were analyzed under headings of harm to "actual potential competition" and to "perceived potential competition." 226 Both involved likely entrants but with a different focus: The former involved a merger of a likely

219. See 1984 Merger Guidelines, infra note 227, § 5.1; see also Citizen Publ'g Co. v. United States, 394 U.S. 131, 138 (1969).

220. Eva M. Dowdell, The Chapter 11 "Shuttle"-Coincidence Or Competitive Strategy?, 71 J. AIR L. \& COM. 669, 673-74 (2006).

221. Julian O. von Kalinowski et al., Antitrust Law \& Trade Regulation, Ch. 3 , § $30.03[7]$ (2d ed. 2015).

222. $I d$.

223. J. Bruce McDonald, Antitrust for Airlines, U.S. DeP’т. Of Just.: Just. News (Nov. 3, 2005), https://www.justice.gov/atr/speech/antitrust-airlines [https://perma.cc/E3YV-9W8L].

224. $I d$.

225. 1984 Merger Guidelines, U.S. DEP'T. OF JUST., https://www.justice.gov/archives/atr/ 1984-merger-guidelines [https://perma.cc/G3PK-AD3F] (last visited Jan. 20, 2017).

226. Id. 
entrant with an incumbent firm that eliminated the entry and thus eliminated the de-concentration effect of entry; while the latter eliminated the downward pressure on price that can be exerted by likely entry and hence limit pricing by the current market participants. Of course, a merger that deconcentrates a market necessarily involves at least one company that at the time of the merger is in a horizontal and competitive relationship to market participants. And a merger involving a company that exerts downward pressure on market prices necessarily is similarly in a horizontal and competitive relationship to the market participants. It would be an apt use of language to describe the firms in these horizontal relationships as competitors. The 2010 Merger Guidelines treat potential competition as a horizontal merger problem, thus, employing a broader approach to horizontal competition than its 1984 and 1992 predecessors. ${ }^{227}$ In its opening sentence these guidelines state its reach as extending to "mergers and acquisitions involving actual or potential competitors." 228

Despite the remarks the DOJ official gave in 2005 quoted above, ${ }^{229}$ the DOJ appears to have given little if any attention in its treatment of airline mergers to possible entry into new city pairs with nonstop service either before or after the new 2010 Merger Guidelines. ${ }^{230}$ The Delta/Northwest merger preceded the 2010 Guidelines; the United/Continental merger took place in the year that the new guidelines were issued; and the American/US Air merger followed three years later. ${ }^{231}$ Yet there is no indication of the Department directing its attention to potential competition issues between and among the merger participants in any of these mergers. ${ }^{232}$ That is probably because the Department does not consider the major airlines as potential competitors. No major airline (except Southwest) is likely to enter a city pair market already served by one or more of the other majors. The closest the majors have come to unsettling their oligopolistic relations was in US Air's "Advantage Program," in which US Air offered a discounted one-stop flight in competition with nonstop flights offered by other

227. See Horizontal Merger Guidelines 7, U.S. Dep’t of Just. (Aug. 19, 2010), https://www.justice.gov/atr/file/810276/download [https://perma.cc/Q4AE-SPQP].

228. Id. at 1; see generally M. Sean Royall \& Adam J. Di Vencenzo, Evaluating Mergers Between Potential Competitors Under the New Horizontal Merger Guidelines, 25 ANTITRUST 33 (2010) (noting, tracing, and discussing the development of the treatment of potential competition from existing firms).

229. See McDonald, supra note 223 and accompanying text.

230. Henry Graber, Why Hasn't the Obama DOJ Blocked More Mergers?, SLATE: MonEY Box (Oct. 11, 2016), http://www.slate.com/blogs/moneybox/2016/10/11/how_things_went_ down_when_the_doj_moved_to_block_the_american_airlines_merger.html[https://perma.cc/VJ97GHFC].

231. See Tal Yellin, The Runway to the Final Four, CNN MONEY, http://money.cnn. com/infographic/news/companies/airline-merger/ [https://perma.cc/UT4J-PNWY] (last visited Jan. 20, 2017).

232. See, e.g., Marilyn Geewax, DOJ Suit Seen Delaying, Not Killing Big Airline Merger, NPR (Aug. 13, 2013), http://www.npr.org/2013/08/13/211729307/doj-suit-seen-delaying-notkilling-big-airline-merger [https://perma.cc/K7R2-VEFP]. 
majors. ${ }^{233}$

A very detailed discussion of the Delta/Northwest merger by Mark Israel, Bryan Keating, Daniel Rubinfeld, and Robert Willig never considers Delta or Northwest as potential competitors to each other on routes they were not already serving (even perhaps to dismiss its probability), while the DOJ's Competitive Impact Statement of the American Airlines/US Air merger similarly completely ignores such competitive concerns while stressing that divested gates and slots as part of the agreed settlement "would expand the presence of potentially disruptive competitors at these strategically important airports." ${ }^{234}$ The original complaint filed uses the phrase "actual and potential" competition, ${ }^{235}$ to attack the merger, but the "potential" part is never discussed. Rather, the key to the Department's approach may lie in the network effects generated by these mergers.

3. Network Effects and Efficiencies.-The first of the recent mergers, Delta/Northwest, is the best documented. ${ }^{236}$ In that case, the merging parties formalized a defense that appears to have been accepted to some extent by the government in all three. ${ }^{237}$ In evaluating the Delta/Northwest merger, the DOJ accepted and used ideas about both the value to passengers of network effects and the cost saving to the airlines of effectuating them. ${ }^{238}$ For consumers, these effects may save trip time, provide a greater density of flights, and allow convenience of scheduling between points or simply allow the traveler to stay with a preferred airline. Whatever the reason, network effects raise the benefit of a product or service to consumers and can be regarded as an increase in quality. Just like any enhancement of quality, they make the product or service more desirable and raise the willingness to pay. Quality improvements that immediately benefit purchasers have always counted positively in merger analysis and are explicitly

233. Conor Shine, More Changes Coming to American Airlines' AAdvantage Frequent Flier Program in August, DALl. News (June 6, 2016), http://www.dallasnews.com/business/airlines/ 2016/06/06/more-changes-coming-to-american-airlines-aadvantage-frequent-flier-program-inaugust [https://perma.cc/XF35-KXPB].

234. CIS at 9, United States v. US Airways Grp., Inc., 38 F. Supp. 3 d 69 (D.D.C. 2014) (No. 1:13-CV-01236), ECF No. 148, https://www.justice.gov/atr/case-document/file/514516/download [https://perma.cc/492D-JC7Y].

235. Complaint at 34, US Airways Grp., Inc., 38 F. Supp. 3d 69 (No. 1:13-CV-01236), https://www.justice.gov/atr/case-document/file/514531/download [https://perma.cc/86CM-UNAG].

236. See, e.g., Mark Israel et al., The Delta-Northwest Merger: Consumer Benefits from Airline Network, in The Antitrust Revolution: Economics, Competition, \& Policy 576 (John E. Kwoka, Jr. \& Lawrence J. White eds., 6th ed. 2014).

237. Id.

238. Id.; see, e.g., Ken Heyer et al., The Year in Review: Economics at the Antitrust Division, 2008-2009, 35 ReV. Indus. ORg. 349 (2009); J. Bruce McDonald, Successful Merger of American Airlines and US Airways Shows Facts, Facts, Facts Critical to Antitrust Review, Tex. Lawbook (June 25, 2014), http://www.jonesday.com/files/Publication/ccb73591-83a2-408f-9624-25d2c1a72 f7d/Presentation/PublicationAttachment/12ae56a5-8152-4331-9805-6cb727542716/ Bruce\%20McDonald\%20AA\%20Antitrust\%20Article.pdf [https://perma.cc/7VRE-HNHX]. 
recognized in successive guidelines. ${ }^{239}$

Figure 1 provides an illustration of the increase in consumer surplus that may accompany the merger of two firms in an industry, such as the airline industry, that generates network effects. ${ }^{240}$ Figure 1 shows two demand configurations and two configurations of cost. ${ }^{241}$ Prior to the merger, we assume that the willingness to pay for a typical trip on either of two (identical) airlines is given by $\mathrm{DD}_{0}$, with marginal revenue $\mathrm{MR}_{0}$ and marginal cost $\mathrm{MC}{ }^{242}$ Hence the price is $\mathrm{B}$ and consumer surplus is $\mathrm{DBP}_{0} \cdot{ }^{243}$ After the merger, the profit-maximizing price remains the same by construction (because the demand curves are drawn to be iso-elastic, although more generally the price could go either up or down), but the demand curve is now $\mathrm{DD}_{1}$ because of the increased value brought about by the merger through enhancing the quality of the product. ${ }^{244}$ Consumer surplus rises to $\mathrm{DCP}_{0} \cdot{ }^{245}$ An alternative way of looking at the problem-and one developed by Israel et al. - is that the marginal willingness to pay at the original volume of traffic is now B' instead of $\mathrm{B}$. $^{246}$

\section{Figure 1}

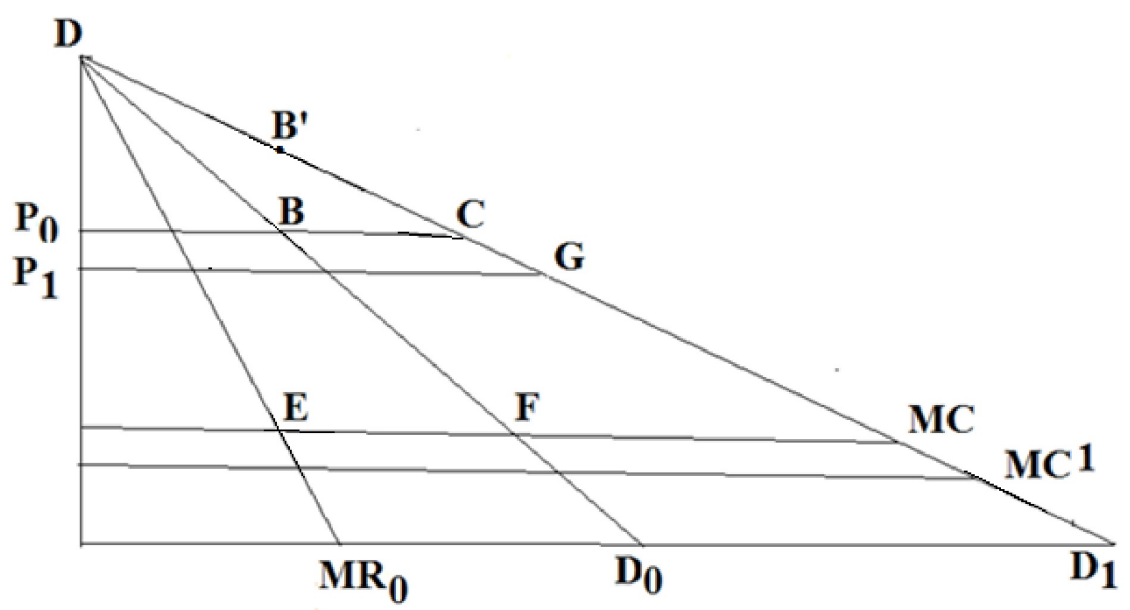

239. See, e.g., Horizontal Merger Guidelines, supra note 227, at 29.

240. See infra Figure 1.

241. Id.

242. Id.

243. Id

244. Id.

245. Id

246. See generally Israel et al., supra note 236. 
Very importantly, even if the observed money price rose slightly above $\mathrm{P}_{0}$ because of increased market power on some routes, the gain in consumer surplus would swamp that loss as the diagram is drawn. ${ }^{247}$ Note that after the merger the diagram would capture the activity of one (identical) half of the merged firm. ${ }^{248}$

In the scenario developed so far, both profits and consumer surplus rise; hence the Williamson tradeoff ${ }^{249}$ does not apply. All of this analysis so far has assumed constant costs by the providers. If there are production cost savings - and the parties in the Northwest-Delta merger claimed them to be very large - then the overall welfare gains are even greater. If fixed costs alone (not shown) are reduced, profits rise without a change in price; if marginal cost falls to $\mathrm{MC}^{1}$, then the observed price of the average trip falls as well.

These issues were raised explicitly or implicitly by all three large legacy mergers considered in this paper. An article by Israel, Keating, Rubinfeld, and Willig, mostly drawn from their research at the behest of the merging firms, reports that the DOJ based its approval of the Delta/Northwest merger on the large consumer benefit generated by network effects and only "modest" price effects. ${ }^{250}$ (The price effects were deemed modest because they affected only a few routes where the merged Delta would lack competition from an independent (arrier. $)^{251}$ A published report on DOJ activity written by law enforcers Ken Heyer, Carl Shapiro, and Jeffrey Wilder ratifies that interpretation by suggesting that a very modest anticipated price effect of the merger would be overbalanced by efficiencies. ${ }^{252}$ Although the Heyer et al. paper did not use the term "network effects," it reported the DOJ did recognize consumer benefit in the merger "by facilitating schedule improvements, by allowing for a more efficient allocation of aircraft across the network, and through marketing synergies that could make the merged carrier's service more attractive to consumers." 253 In other words, these authors are expanding the meaning of "efficiencies" from its usual meaning of cost reduction to a broader meaning that includes consumer benefits resulting from network effects.

Heyer et al. accepted an analysis based on the airlines' own assumptions about the dollar equivalence of various quality enhancements rather than the much larger consumer gains from the model prepared by Israel et al. for Delta and Northwest. ${ }^{254}$ They still found consumer benefits vastly in excess of any forecast price increases on the routes where the two firms had confronted each other as the sole legacy carriers. ${ }^{255}$ But greater head-to-head competition between the firms

247. See Figure 1.

248. Id.

249. See Oliver E. Williamson, Economies as an Antitrust Defense: The Welfare Tradeoffs, 58 The Am. ECON. Rev. 18 (1968).

250. Israel et al., supra note 236 , at 582 .

251. Id. at 581 .

252. Heyer et al., supra note 238.

253. $I d$.

254. $I d$.

255. $I d$. 
had they remained independent was not even considered-either by the firms or the agencies. ${ }^{256}$ This could be due to the usual DOJ time horizon of only two years ${ }^{257}$ but it could also suggest a more fundamental recognition of the structural unlikelihood that entrenched oligopolists would engage in strong head-to-head competition in an industry with almost perfectly transparent, instantaneously available prices and only minor product innovation. It necessarily must also reflect the barrels of red ink that had marked the industry in most previous years.

It is important to note that consumer valuation in the three merger cases is based entirely on estimates of willingness to pay without distinction about why consumers find the merger valuable. ${ }^{258}$ This evaluation thus accepts the marketing-generated preferences noted earlier. But this is a convention implicitly accepted in most modern antitrust analyses. Increased willingness to pay based on individual preferences rather than on an external evaluation of product characteristics respects consumer sovereignty. ${ }^{259}$

The original complaint against American Airlines describes the pricing policies of the legacy airlines. ${ }^{260}$ The pricing policies involve tentative price leadership, price changes withdrawn when not followed, and close to uniform pricing in short-term equilibrium for various "brands"- each of which has its own loyal followings but apparently cannot be consistently ordered in overall quality. ${ }^{261}$ This pattern resembles the decades-long cigarette oligopoly featured in myriad economic textbooks. ${ }^{262} \mathrm{~A}$ major lesson emerged from two landmark antitrust cases involving the cigarette industry, thirty-five years apart. The breakup of the original American Tobacco Co. in $1911^{263}$ could not have prevented the successor companies from adopting monopoly-like pricing when three of them controlled most of the market. Thus, the case against the successor companies in $1946^{264}$ showed them engaged in the kind of parallel pricing that is characteristic of tight oligopolies. ${ }^{265}$ As economists and legal scholars have long

256. Id.

257. Constance K. Robinson, Dir. of Operations, Antitrust Div.: Dep't of Just., Address at The Association of the Bar of the City of New York (Sept. 30, 1996), https://www.justice.gov/atr/ speech/bank-mergers-and-antitrust-trends [https://perma.cc/D85E-SBH9].

258. See, e.g., Oliver Richard, Flight Frequency and Mergers in Airline Markets, 21 INT'L J. INDUS. ORG. 907 (2003) (discussing how studies tend to focus only on price instead of other consumer choices like flight frequency).

259. See generally Neil W. Averitt \& Robert H. Lande, Consumer Sovereignty: A Unified Theory of Antitrust and Consumer Protection Law, 65 ANTITRUST L.J. 713 (1997).

260. Complaint at 15-18, United States v. US Airways Grp., Inc., 38 F. Supp. $3 d 69$ (D.D.C. 2014) (No. 1:13-CV-01236).

261. Id.

262. See, e.g., Dennis W. Carlton \& Jeffrey M. Perloff, Modern Industrial OrganizATION 358, 656 (4th ed. 2005).

263. See United States v. Am. Tobacco Co., 221 U.S. 106 (1911).

264. See Am. Tobacco Co. v. United States, 328 U.S. 781 (1946).

265. Id. at 807-08. Another parallel with the airlines is that the major tobacco firms were also found guilty of predatory pricing against entrants pursuing a low-price strategy. CARLTON \& 
recognized, there are no feasible policies to combat "parallel pricing" and to impose price competition. ${ }^{266}$

The Delta/Northwest merger differed from the two that followed because the approval did not require the firms to give up any gates or slots. Approval rested on an increase in consumer valuation of likely changes by the two merging parties on the apparent assumption that they were not imminently likely to engage in more competitive behavior towards each other. The settlement did not necessitate any quid pro quo to increase competition in the market. In contrast, both of the other approved mergers involved the enhancement of access by LCCs to "constrained airports.",

Although the United/Continental merger of 2010 was not challenged, and therefore no Competitive Impact Statement was required by the Tunney Act, ${ }^{268}$ the DOJ discussed its United/Continental action in the Statement explaining its ultimate approval of the American Airlines/US Air merger. ${ }^{269}$ The explanation bears quoting at length:

Past antitrust enforcement demonstrates that providing LCCs with access to constrained airports results in dramatic consumer benefits. In 2010 , in response to the United States' concerns regarding competitive effects of the proposed United/Continental merger, United and Continental transferred 36 slots, three gates and other facilities at Newark to Southwest. Southwest used those assets to establish service on six nonstop routes from Newark, resulting in substantially lower fares to consumers. For example, average fares for travel between Newark and St. Louis dropped $27 \%$ and fares for travel between Newark and Houston dropped $15 \%$. In addition, Southwest established connecting service to approximately 60 additional cities throughout the United States.

The proposed remedy will require the divestiture of almost four times as many slots as were divested at the time of the United/Continental merger, plus gates and additional facilities at key airports throughout the country. In total, the divestitures will significantly strengthen the purchasing carriers, provide the incentive and ability for those carriers to invest in new capacity, and position them to provide more meaningful competition

PERLOFF, supra note 262, at 358.

266. Donald F. Turner, The Definition of Agreement Under the Sherman Act: Conscious Parallelism and Refusals to Deal, 75 HARV. L. ReV. 655, 661-63 (1962); see also William H. Nichols, Price Policies in the Cigarette Industry 401 (1951).

267. See, e.g., McDonald, supra note 238, at 2-3.

268. The Antitrust Procedures and Penalties Act, 15 U.S.C. $§ 16$ (2012), popularly known as the Tunney Act, requires a court review of DOJ actions on challenged mergers and acquisitions as well as a competitive impact statement prepared by the agency.

269. CIS at 10, United States v. US Airways Grp., Inc., 38 F. Supp. 3d 69 (D.D.C. 2014) (No. 1:13-CV-01236), ECF No. 148, https://www.justice.gov/atr/case-document/file/514516/download [https://perma.cc/492D-JC7Y]. 
system-wide. ${ }^{270}$

The original complaint against the American/US Air merger devoted much space to the competition provided to the other legacy carriers by US Air, which DOJ argued engaged in more price competition than other legacy carriers (through its "Advantage Fares" on connecting flights) because its hubs were less advantageously placed. ${ }^{271}$ But DOJ may have decided that it could achieve both higher quality service and the possibility of increased price competition by approving the merger. A similar calculation may have underlain the approval of United/Continental: In each case the loss of possibly largely ineffective competition was sacrificed for the more promising price-reduction policy of encouraging the LCCs along with some increased product quality and cost saving.

\section{An Interpretation: How DOJ's Merger Evaluations in the Airline Industry Differ from Its Normal Merger Evaluations}

Prices are the focus of routine merger evaluation. ${ }^{272}$ The analysis begins with the Department's assessment of the relevant market, using a hypothetical monopolist framework set forth in the guidelines. ${ }^{273}$ The idea is to equate the relevant market for merger evaluation with the geographic and product space in which a hypothetical monopolist could profitably impose a small but significant and non-transitory increase in price. ${ }^{274}$ Post-merger entry is cognizable only if it is sufficient to restore price to pre-merger levels within a limited period. ${ }^{275} \mathrm{In}$ airline mergers this exclusive focus on price and price effects has been replaced by a broader and more encompassing inquiry.

Several factors explain this broader analytical approach. First, the price effects of the recent airline mergers, based on an extensive body of econometric research, were expected to be small. These minimal price effects may be partially explained by competition from the LCCs. It may also be due to the fact that the airlines have already maximized their pricing power as Brueckner has suggested. ${ }^{276}$ These two possible explanations are not inconsistent and both may play a role.

Note that a city-pair market composed of three carriers would minimally have an HHI of over 3000 and would be defined by the merger guidelines as a highly concentrated market. ${ }^{277}$ Any merger that would raise the HHI in a highly concentrated market by more than 200 points would be deemed presumptively unlawful. ${ }^{278}$ According to the Brueckner studies, the price effects of two-to-one

270. Id.

271. Complaint at 4-5, US Airways Grp., Inc., 38 F. Supp. 3d 69 (No. 1:13-CV-01236).

272. See Horizontal Merger Guidelines, supra note 227, § 1.

273. Id. § 4.1.1.

274. Id.

275. Id. §9.3.

276. See generally BRUECKNER, supra note 110.

277. See Horizontal Merger Guidelines, supra note 227, § 5.3.

278. Id. 
mergers in city-pair markets are significant but low, about the same (or less) than a SSNIP. ${ }^{279}$ This was subsequently interpreted by Borenstein to mean that the recognition of mutual dependence comes at a lower threshold. ${ }^{280}$ Such reasoning could explain the DOJ's apparent exemption of the airline industry from the normal presumption of illegality that the guidelines attach to high concentration. Although the guidelines state that the SSNIP "is not a tolerance level for price increases resulting from a merger, ${ }^{, 281}$ the DOJ has apparently tolerated some price increases in that amount because the likely price increases (in the recent mergers under review) were more than offset by quality-related consumer benefits.

This brings us to network effects as the source of consumer benefits. As pointed out above, the hub-and-spoke organization of the large airlines was a largely unanticipated cost-saving device having demand-side as well as supplyside ramifications. ${ }^{282}$ This organizational economy benefited consumers by lowering their costs of traveling between many cities. ${ }^{283}$ Mergers between airlines, whose networks are in substantial part non-overlapping, add to consumer convenience by enabling consumers to use a larger (merger-enhanced) network without changing airlines. ${ }^{284}$ In routine merger analysis, the merger partners do not normally generate network effects, so there is no corresponding consumer benefit to evaluate. This, then, makes the evaluation of airline mergers again different from normal merger evaluation. In airline mergers, the antitrust analysis cannot focus exclusively on price effects, but must also take account of these quality enhancements when they are present, because they are part of standard consumer welfare analysis. ${ }^{285}$ It appears that the DOJ did just that, and concluded that the price effects of each of these mergers were offset by the quality effects generated by combining networks.

In addition, in two of the recent mergers (United/Continental and American/US Air), the DOJ conditioned approval upon the merger partners transferring significant numbers of gates or landing slots to Southwest, JetBlue, or other LCCs. ${ }^{286}$ This could be viewed as a frontal attack on a series of antitrust bottlenecks. Because gates and slots are necessary for the LCC to compete and they are in short supply at a number of major airports, their transfer to LLCs creates the conditions in which LLC competition at these airports can be

279. The agencies enforcing the guidelines most often use a SSNIP of $5 \%$ of the consumer price. See id. $\S 4.1 .2$.

280. Borenstein, supra note 42 , at 10.

281. See Horizontal Merger Guidelines, supra note 227, § 4.1.1.

282. See Borenstein \& Rose, supra note 33 , at 41.

283. Id.

284. See Horizontal Merger Guidelines, supra note $227, \S 3.5$.

285. The merger guidelines recognize the theoretical relevance of the non-price effects of mergers. Id. $\S 4.1 .2$ (stating the enforcement agencies methodology is concentrated on price effects because those effects are quantifiable "not because price effects are more important than non-price effects").

286. Id. 
significantly strengthened. ${ }^{287}$

The required gate and slot transfers bear an analytical similarity to the now disfavored essential facilities doctrine. ${ }^{288}$ That doctrine (in most of its variations) requires an owner of a facility needed to compete to share with rivals when it is impossible or impractical for them to duplicate it. Where gates and slots are in short supply in a number of airports, they take on a role analytically similar to the role played by the terminal facilities. They are limited in number and the merger participants in both mergers controlled critical numbers of gates and slots, reinforcing their market power and impeding competition from LCCs. ${ }^{289}$ The airport situation, however, takes a somewhat different form. In the airport cases, there is a public regulator (the DOT and the local airport authorities) of a fixed or nearly fixed essential facility that is used to capacity. Of these public regulators, only the DOT is able to regulate gate and slot allocations beyond the confines of a single airport. ${ }^{290}$ Although the DOJ has succeeded the DOT as merger enforcer, the DOT retains at least some authority over competition issues under section 411. Competition would be furthered if the DOT allotted the gates and slots in the public interest. So stated, this problem resembles Trinko, ${ }^{291}$ where Justice Scalia, writing for the Court, determined that the problem-access by rivals to elements of the telephone network controlled by Verizon-was a regulatory one within the cognizance of the Federal Communications Commission (FCC) and not within the domain of antitrust. ${ }^{292}$ Verizon could be read as indicating the allocation of gates and slots is a matter for the DOT. In the merger cases under review, the DOJ has used its jurisdiction over mergers to preempt any attempt by the DOT to address the allocation of gates and slots. ${ }^{293}$ In context, this aggressive use of antitrust by the DOJ appears fully justified: The DOJ is well within its authority to take competitive conditions into account in settlements; and its actions are likely to further the congressional purpose of enhanced antitrust enforcement underlying the transfer of enforcement authority over mergers from the DOT to the DOJ.

As a condition for approving the United/Continental merger, the DOJ

287. Id

288. That doctrine, as exemplified by the St. Louis Terminal RR case involved a group of railroads controlling access to terminal facilities needed by all railroads to compete in cross-country traffic. United States v. Terminal R.R. Ass'n, 224 U.S. 383, 390-93 (1912). The Court ruling provided access to those facilities by all of the competing railroads. Id. at 411-13. In his majority opinion in Verizon Communications Inc. v. Law Offices of Curtis V. Trinko, 540 U.S. 398, 410-11 (2004), Justice Scalia denied that the Court had ever recognized an essential facilities doctrine. Although the Court did not employ the term, most antitrust observers believe that the doctrine originated in Terminal Railroad.

289. Id. at 79-80.

290. 49 U.S.C. $\S 41714$ (2012).

291. 540 U.S. at 411-16.

292. Id. at 410-11.

293. See generally id.; see also United States v. US Airways Grp., Inc., 38 F. Supp. 3d 69 (D.D.C. 2014). 
required that the parties transfer thirty-six slots and three gates at Newark to Southwest. ${ }^{294}$ In the American/US Air merger, the DOJ required the parties to divest 104 slots at Washington's Reagan National and thirty-four slots at New York's LaGuardia airports. ${ }^{295}$ Sixteen of the affected slots at Reagan were already leased by JetBlue from American, but the final judgment makes these slots permanently available to JetBlue. ${ }^{296}$ The remaining eighty-eight slots at Reagan will be divested to at least two carriers approved by the DOJ. ${ }^{297}$ The merger approval conditions require the divestiture of thirty-four slots at LaGuardia. ${ }^{298}$ Ten of these slots were already leased to Southwest, but the final judgment awards them permanently to Southwest. ${ }^{299}$ The remaining twenty-four slots will be awarded to carriers approved by the DOJ. ${ }^{300}$ The merger approval conditions also require the divestiture to airlines approved by the DOJ of two gates at each of the following cities: Chicago (O'Hare), Los Angeles, Boston, Miami, and Dallas. ${ }^{301}$

Slot and gate divestitures aim to stimulate competition in the context of the particular structure of the U.S. airline industry. The DOJ's strategy is apparently based on a recognition that price competition is unlikely among the legacy carriers whose marketing practices are interdependent. Instead, its strategy relies on the LCCs to generate price competition. So far, the LCCs have operated with different incentives and business plans than have the legacies, and the LCCs pricing policies have diverged significantly from the legacy carriers, generating a strong downwards pressure on prices. ${ }^{302}$

In approving the American/US Air merger, the DOJ countenanced the elimination of the US Air's Advantage Fare program, a program under which US Air undercut legacy nonstop fares on US Air flights requiring a stop..$^{303}$ This was a major objection to the merger in the original complaint, ${ }^{304}$ but the concern was ultimately shelved. Why? The DOJ may well have thought that the Advantage Fare program contributed less to price competition than would the new LCC competition that would emerge because of the slot and gate transfers that were part of the settlement.

In summary, the LCCs played a critical role in the approval of the last two

294. CIS at 10, US Airways Grp., Inc., 38 F. Supp. 3d 69 (No. 1:13-cv-01236).

295. Final Judgment at 3-4, US Airways Grp., Inc., 38 F. Supp. 3d 69 (No. 1:13-cv-01236); CIS at 8 US Airways Grp., Inc., 38 F. Supp. 3d 69 (No. 1:13-cv-01236).

296. Final Judgment at 7, US Airways Grp., Inc., 38 F. Supp. 3d 69 (No. 1:13-cv-01236); CIS at 10-11, US Airways Grp., Inc., 38 F. Supp. 3d 69 (No. 1:13-cv-01236).

297. Final Judgment at 3-4, US Airways Grp., Inc., 38 F. Supp. 3 d 69 (No. 1:13-cv-01236).

298. Id. at 8 .

299. Id. at 2,8 .

300. Id. at 4,8 .

301. Id. at 4,9 .

302. See generally VASIGH, supra note 53, at ch. 12.

303. See United States v. US Airways Grp., 38 F. Supp. 3d 69, 77 (D.D.C. 2014) (describing US Airways "Advantage Fares" program).

304. Complaint at qף 5-7, US Airways Grp., Inc., 38 F. Supp. 3d 69 (No. 1:13-cv-01236). 
mergers considered. Previous research provided grounds for expecting only a minimal price effect from the mergers, partly due to existing LCC competition. ${ }^{305}$ In addition, the mandated gate and slot transfers were keyed to opening markets to substantially increase that competition. ${ }^{306}$ Actual and anticipated price competition from the LCCs allowed the estimated value of enhanced quality from the mergers to outweigh estimated price effects. ${ }^{307}$

\section{E. Apparent Merger Results So Far}

Since the mergers, the airline industry has recovered from the effects of the recession, and the industry is earning record profits. ${ }^{308}$ This profitability extends to all three of the merged legacy carriers. ${ }^{309}$ This resurgent demand has at least temporarily solved the financial problems that have plagued the industry in the past. Is there evidence that the DOJ's use of network-generated consumer surplus as a tool of merger evaluation generates sound policy?

Any indication of increased demand from network effects alone based on market share changes would be highly tentative, given that the data are completely uncontrolled, especially for prices and the fact that airline network changes were overlapping and management changes from mergers often create temporary difficulties. Nevertheless, the Delta/Northwest merger may have generated some effects that are indicative of the quality enhancement. Although both firms stumbled in the year prior to the merger, the combination resulted in an immediate, sustained, and considerable expansion of share, in conformity with the model in Figure $1 .{ }^{310}$

Table 1

Delta and Northwest Market Shares

(Enplanements in thousands. Market shares computed from enplanements.)

\begin{tabular}{|c|c|c|c|c|c|c|c|c|c|}
\hline \multirow{2}{*}{ Year } & \multicolumn{2}{|l|}{ Deita } & \multicolumn{2}{|c|}{ No........nthrest... } & \multicolumn{2}{|c|}{.....Boh.or.Mnered. } & \multirow{2}{*}{$\begin{array}{c}\text { total } \\
\text { Ennanements }\end{array}$} & \multirow{2}{*}{$\begin{array}{c}\text { Erplanements } \\
\text { Change }\end{array}$} & \multirow{2}{*}{$\begin{array}{l}\text { Share } \\
\text { Change }\end{array}$} \\
\hline & Explanements & Share & Fonkenementa & Share & Fnglanements & Share & & & \\
\hline 2006 & 63.496 & $964 \%$ & 45.141 & $6.86 \%$ & 108637 & $16.50 \%$ & 658.363 & & \\
\hline 2007 & 61.599 & $907 \%$ & 43.812 & $645 \%$ & 105412 & $15.52 \%$ & 679.168 & $-297 \%$ & $-5.94 \%$ \\
\hline 200.8 & 59.376. &. $.211 \%$ & 38.51.1. & $5 . \%$ & .97 .887 & $15.02 \%$ & 651.709 & $.7 .1 .4 \%$ & $-323 \%$ \\
\hline $2 M O P$ & $. .55,7 n 0$ &. $.9 .01 \%$ & $.32,624$ & $5.28 \%$ & .88 .333$. & $.14 .29 \%$ & 618,061 & $.9 .76 \%$ & $-4.8 .5 \%$ \\
\hline $201 . \Omega$ & $90,1,41$. &. $.14 .32 \%$ & & & $. .9 n, 141$ & $.14 .32 \%$ & 620.538 & $\ldots .0 .0 \%$ & $0.1 .8 \%$ \\
\hline 2011 & 92.864 & $14.55 \%$ & & & 92864 & $14.55 \%$ & 638.247 & $3.02 \%$ & $1.62 \%$ \\
\hline 2012 & S5.64h. & $14.89 \%$ & & & 95641 & $.14 .89 \%$ & 642,289 & $2.99 \%$ & $2.3 .4 \%$ \\
\hline 201.3. &. .98 .590$. & $.15 .27 \%$ & & & .98 .590$. & $.15 .27 \%$ & 645.679 & $3.0 .6 \%$ & $2.5 .4 \%$ \\
\hline 2014 & 106.424 & $1606 \%$ & & & 106424 & $1606 \%$ & 662.831 & $795 \%$ & $5.15 \%$ \\
\hline 2015 & 115.074 & $16.53 \%$ & & & 115.074 & $16.53 \%$ & 696.027 & $8.13 \%$ & $297 \%$ \\
\hline
\end{tabular}

305. See US Airways Grp., Inc., 38 F. Supp. 3d at 77-79.

306. CIS at 8-10, US Airways Grp., Inc., 38 F. Supp. 3d 69 (No. 1:13-cv-01236).

307. See US Airways Grp., Inc., 38 F. Supp. 3d at 77-79.

308. Mouawad, supra note 69.

309. Id.

310. See supra Figure 1. 
The United/Continental merger, however, seems to tell a different story. In 2010 when the two airlines announced their intention to merge until 2015, the combined market share declined each year, although the rate of decline had been slowing. ${ }^{311}$ The decline was reversed in 2015 , however, and the merged airline's market share increased by almost two percent. ${ }^{312}$

Table 2

United and Continental Market Shares

(Enplanements in thousands. Market shares computed from enplanements.)

\begin{tabular}{|c|c|c|c|c|c|c|c|c|c|}
\hline \multirow{2}{*}{ Year } & \multicolumn{2}{|l|}{ United. } & \multicolumn{2}{|c|}{ Continental. } & \multicolumn{2}{|c|}{ Boch.or Nored.... } & \multirow{2}{*}{$\begin{array}{c}\text { Total } \\
\text { Emplanements }\end{array}$} & \multirow{2}{*}{$\begin{array}{c}\text { Enplanements } \\
\text { Change }\end{array}$} & \multirow{2}{*}{$\begin{array}{l}\text { Share } \\
\text { Change }\end{array}$} \\
\hline & Enplanements & Share & Enplanements & Share & Emplanements & Share & & & \\
\hline 2006 & 57202 & $860 \%$ & 35795 & $544^{2} \%$ & 930025 & $14.13 \%$ & 658.363 & & \\
\hline 20007. & .56 .420 & $8.31 \%$ & 37.117 & $5.47 \%$ & 93537 & $13.77 \%$ & 168 & $0.55 \%$ & $-2.53 \%$ \\
\hline 2008. & 51.681. & $7.92 \%$ & .34 .525 & $5.3 .0 \%$ & 86206 & $13.23 \%$ & 6517.09 & $-7.84 \%$ & $-3.9 .5 \%$ \\
\hline 2000 & $45,583$. & $.7 . .38 \%$ & $31,05.5$ & $.5 .17 \%$ & $77,5,37$ & $12.5 .5 \%$ & $6.18,0.51$. & $-10.0 \curvearrowleft \%$ &. $.5 .1 \ldots \%$ \\
\hline 2010 & 43.323 & $6.88 \%$ & 30.654 & $4.87 \%$ & 73977 & $11.75 \%$ & 629.538 & $4.59 \%$ & $-6.33 \%$ \\
\hline 2011 & 39.551 & $620 \%$ & 31243 & $490 \%$ & 70794 & $11.09 \%$ & 638.247 & $4.30 \%$ & $-5.61 \%$ \\
\hline 2012 & ..67.629. & $.10 .53 \%$ & & & 67.629 & $10.53 \%$ & 642.289 & $4.47 \%$ & $-5.07 \%$ \\
\hline 201.3. & 65.221. & $.10 .10 \%$ & & & 65221 & $.10 .1 .0 \%$ & 645.679 & $-3.5 \% \%$ & $.4 .0 .7 \%$ \\
\hline 2014 & 64.796 & $978 \%$ & & & 64796 & $9.78 \%$ & 662831 & $-2.65 \%$ & $-3.22 \%$ \\
\hline 2015 & 6.310 & $9.96 \%$ & & & 69.310 & $996 \%$ & 696.027 & $697 \%$ & $1.86 \%$ \\
\hline
\end{tabular}

The attraction of a combined network cannot be discerned in the American/US Air merger shown in Table $3 .^{313}$ The merger did not take place until the settlement with the DOJ in late 2013. ${ }^{314}$ In 2013, the year in which the merger was being litigated, the combined carriage of the constituent airlines increased by $2.3 \%$ and market share by $1.8 \%$, but in 2014 , the first year of operation of the merged airline, its growth declined to $1.7 \%$ and market share dropped by nearly one percent. ${ }^{315}$ The last full year for which data is available, 2015, was a boom year for the industry as a whole, but the merged airline saw an enplanement increase of less than one percent and a nearly four percent loss of market share. ${ }^{316}$

311. See infra Table 2.

312. See infra Table 2 .

313. See supra Table 3.

314. United States v. US Airways Grp., 38 F. Supp. 3d 69, 72 (D.D.C. 2014).

315. See infra Table 3.

316. See infra Table 3. 
Table 3

American and US Air Market Shares

(Enplanements in thousands. Market shares computed from enplanements.)

\begin{tabular}{|c|c|c|c|c|c|c|c|c|c|}
\hline \multirow{2}{*}{ Year } & \multicolumn{2}{|c|}{ Americanth. } & \multicolumn{2}{|l|}{ US.Air. } & \multicolumn{2}{|c|}{ Both. Rx M.erend. } & \multirow{2}{*}{$\begin{array}{c}\text { Total } \\
\text { Emplanements }\end{array}$} & \multirow{2}{*}{$\begin{array}{c}\text { Enplanements } \\
\text { Change }\end{array}$} & \multirow{2}{*}{$\begin{array}{l}\text { Share } \\
\text { Change }\end{array}$} \\
\hline & Emplanements & Share & Enplanements: & Share & Emlanements & Share & & & \\
\hline 2006 & 76.813 & $1167 \%$ & 31.886 & $4.84^{2} \%$ & 108700 & $16.51 \%$ & 658.363 & & \\
\hline 20007 & .76 .581$. & $.11 .28 \%$ & 32221 & $5.48 \%$ & 1138.02 & $.16 .7 .6 \%$ & 679.168 & & $1.49 \%$ \\
\hline 2008 & 71.564 & $10.98 \%$ & 48.545 & $7.45 \%$ & 120109 & $18.43 \%$ & 65117.29 & $5.54 \%$ & $9.99 \%$ \\
\hline 2009 & 66169 & $1071 \%$ & 44.554 & $721 \%$ & 110723 & $17.91 \%$ & 618.051 & $-7.81 \%$ & $-279 \%$ \\
\hline 2010 & 65.734 & $10.44 \%$ & 45.180 & $7.18 \%$ & 110914 & $17.62 \%$ & 622.538 & $0.17 \%$ & $-1.66 \%$ \\
\hline 2011 & 65.253 & $1022 \%$ & 46208 & $724^{2} \%$ & 111462 & $17.46 \%$ & 638.247 & $0.49 \%$ & $-0.88 \%$ \\
\hline 2012 & 65.027. & $10.12 \%$ & 47.481320 & $7.39 \%$ & .112508 & $.17 .52 \%$ & 642.289 & $0.9 .4 \%$ & $0.30 \%$ \\
\hline 201.3 & $65,07 n$ & $1.0 .08 \%$ & .50237109 & $.7 .7 .5 \%$ & $. .1 .1 .5,1,07$ & $.17 .8 .8 \%$ & 645,679 & $.2 . .3 .1 \%$ & $\ldots 1.77 \%$ \\
\hline 2014 & 66402 & $1002 \%$ & 50685595 & $7.65 \%$ & 117.087 & $17.66 \%$ & 662.831 & $1.72 \%$ & $-0.91 \%$ \\
\hline 2015 & 93.341 & $13.41 \%$ & 24790680 & $3.56 \%$ & 118.131 & $1697 \%$ & 696.027 & $0.89 \%$ & $-3.92 \%$ \\
\hline
\end{tabular}

Perhaps the United/Continental merger will yet expand its output beyond premerger levels. Perhaps the American/US Air merger will attain robust growth. At the present time, however, only the Delta/Northwest merger appears to be generating the increased demand that network effects seemed to promise. The clearest conclusion from the data so far is that any such effects appear to be easily lost among other factors determining the demand for a specific airline.

\section{CONCLUSION}

The airline industry's unique characteristics support a merger analysis that differs in critical ways from traditional merger analysis. Indeed, because other industries such as the communications and software industries also generate network effects, it is possible that antitrust merger analysis will be affected in these industries as well. ${ }^{317}$ The DOJ clearly accepted the argument that a merger between largely non-overlapping airline networks can generate significant consumer surplus without offsetting price effects. The first of the three major recent mergers may confirm the soundness of that conclusion, but the jury is clearly still out on the other two. ${ }^{318}$ One possibility is that network benefits have been exaggerated, and the reduced number of players nationally may allow for a greater exercise of collective market power. Or the very dramatic recent increase in airline profitability may yet disappear as the major players probe new dimensions of competition to increase firm profitability. In any event, the presence of the LCCs is providing competition for the legacy carriers, thus dampening the effects of the legacies' increased recognition of mutual dependence. This is greatly facilitated by far more easily available information on prices by the travelling public brought by the digital age. The DOJ's recognition of the consumer welfare impact of the LCCs has focused the DOJ on gate and slot transfers to increase LCC competitive impact.

317. See supra Part I.E.

318. See supra Part II.E. 
Forecasting the future of the airline industry has been hazardous in the past, and certainly remains so. Southwest, the largest of the LCCs, is now the largest originator of domestic air traffic, ${ }^{319}$ and, although it has been widely recognized as generating significant downward pressure on the prices of the legacy carriers that compete with it, both its costs and its prices appear to have been rising relative to the legacy carriers. ${ }^{320}$ But JetBlue, another of the LCCs, has grown to be the fifth largest carrier, ${ }^{321}$ and it also produces strong downward pricing pressure on the legacy carriers that compete with it. More generally, if, as appears likely, the major carriers will engage in only muted competition against each other in the future, market performance will turn largely on the discipline provided by the LCCs and their support by legal authority.

319. Departures Performed by Unique Carrier for 2016, Bureau TrAnSP. StAT., http://www. transtats. bts.gov/ [https://perma.cc/WCE5-24ZC] (last visited Jan. 20, 2017).

320. Bachman, supra note 161.

321. On-Flight Market Passengers Enplaned by UniqueCarrier for 2015, BUREAU TRANSP. STAT., http://www.transtats.bts.gov/ [https://perma.cc/E4RV-7V83] (last visited Jan. 20, 2017). 